\title{
QCONOMIC REVIEW
}

1997 Quarter 4

Generational Accounts for the United States: 2 An Update

by Jagadeesh Gokhale,

Benjamin R. Page, and John R. Sturrock

Does Intervention Explain the

Forward Discount Puzzle?

by William P. Osterberg

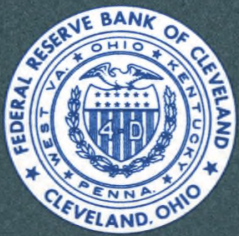

FEDERAL RESERVE BANK OF CLEVELAND 
ECONOM I C REVIEW

1997 Quarter 4

Vol. 33, No. 4

\section{Generational Accounts for the United States: An Update}

by Jagadeesh Gokhale, Benjamin R. Page, and John R. Sturrock

Although the generational stance of U.S. fiscal policy has improved considerably over the last two years, it remains substantially imbalanced and is unsustainable. If living generations' continue to be treated as they are under current policy, future generations will have to pay almost half of their lifetime labor incomes in net taxes to balance the government's books. This is more than 70 percent larger than the 28.6 percent today's newborns are slated to give up. In this article, the authors look at what it would take to restore a generationally balanced fiscal policy. The possible solutions include an immediate and permanent income tax hike of 20 percent, a 19 percent cut in transfer payments, or a 15 percent reduction in government purchases. These measures may seem harsh, but waiting to act will make the task even more difficult.

\section{Does Intervention Explain the Forward Discount Puzzle? \\ by William P. Osterberg}

This article uses official 1985-91 intervention data to investigate the impact of U.S. and German central-bank interventions on the forward discount puzzle for two exchange rates - the German mark/U.S. dollar and the Japanese yen/U.S. dollar. Evidence on the importance of intervention is strongest for the mark/dollar exchange rate. However, whereas Flood and Rose (1996) found that the puzzle was stronger for floating than for fixed exchange rate regimes, this study finds it to be stronger during periods of intervention than at other times. Thus, if intervention is associated with fixed-rate regimes, the results reported here are inconsistent with those of Flood and Rose.
Economic Review is published quarterly by the Research Department of the Federal Reserve Bank of Cleveland. Copies of the Review are available through our Corporate Communications \& Community Affairs Department. Call 1-800-543-3489 (OH, PA, WV) or 216-579-2001, then immediately key in 1-5-3 on your touch-tone phone to reach the publication request option. If you prefer to fax your order, the number is 216-579-2477.

Economic Review is available electronically through the Cleveland Fed's site on the World Wide Web: http://www.clev.frb.org. We also offer a free online subscription service to notify readers of additions to our Web site. To subscribe, please send an email mesage to econpubs-on@clev.frb.org.

Managing Editor: Tess Ferg Editor: Michele Lachman Design: Michael Galka Typography: Liz Hanna

Opinions stated in Economic Review are those of the authors and not necessarily those of the Federal Reserve Bank of Cleveland or of the Board of Governors of the Federal Reserve System.

Material may be reprinted provided that the source is credited. Please send copies of reprinted material to the editors. 


\section{Generational Accounts for the United States: An Update}

\author{
by Jagadeesh Gokhale, \\ Benjamin R. Page, and \\ John R. Sturrock
}

\begin{abstract}
Jagadeesh Gokhale is an economic advisor at the Federal Reserve Bank of Cleveland, and Benjamin R. Page and John R. Sturrock are economic analysts at the Congressional Budget Office. The authors thank Robert Kilpatrick and Laurence Kotlikoff for helpful discussions. This article is reprinted, with additions, from Generational Accounts around the World. eds. Alan J. Auerbach, Laurence J. Kotlikoff, and Willi Leibfritz (Chicago: University of Chicago Press, forthcoming), by permission of the publisher. Copyright 1998 by the National Bureau of Economic Research. All rights reserved.
\end{abstract}

The first source of financing (the government's current net wealth) is given. The second source (the present value of current generations' net taxes) is obtained by estimating the per capita net taxes that each living generation will pay during its remaining lifetime, actuarially discounting the payments back to the present, and summing over the discounted values to obtain a generational account for each generation. ${ }^{3}$ Those respective generational accounts are then added over everyone currently alive to find their combined contribution to prospective purchases. Having calculated the present value of prospective purchases and the first two sources of financing, the third source (the present value of unborn generations' net taxes) can be computed as a residual. This residual expresses the fiscal burden that must be placed on unborn generations for the government to remain solvent forever.

1 Net taxes are taxes minus transfers.

2 The technique of generational accounting was developed in Auerbach, Gokhale, and Kotlikoff (1991). See also Auerbach, Gokhale, and Kotlikoff (1994).

3 An actuarial calculation allows for the fact that the current number of people in a generation will later be decreased by death or increased by immigration. 
Finally, generational accounting compares all living generations on a lifetime basis by estimating the effective rate at which each pays net taxes over its entire life - its lifetime net tax rate. The method estimates past and prospective net taxes and labor income that each living generation earns over its life. The lifetime net tax rate is then stated as a percentage, namely, the present value, at birth, of a generation's lifetime net taxes as a share of the present value, at birth, of its lifetime labor income.

As an illustrative device, generational accounting further supposes that future generations share the residual burden equally (with an adjustment for economic growth). This implies that males and females bom in each future year will face the same lifetime net tax rate. Thus, the method compares all generations on the same basis - the effective rate at which they pay net taxes over their entire lives.

Generational accounts help us judge whether fiscal policy is generationally balanced, that is, whether future generations will pay, on average, the same lifetime net tax rate as current newborns (people born in the base year). A generationally balanced policy is sustainable, meaning that it can be followed forever without changing its scheduled effective rates for taxes, transfers, and spending. Conversely, a policy is imbalanced (or unsustainable) if it implies that future generations must pay a different net tax rate than current newborns.

An imbalance implies that to pay for prospective purchases, the scheduled rates of effective net taxes must change - if not for current generations, then for future ones. If an imbalance implies that the future rate will be higher than the current rate, the rate must eventually rise. If the imbalance is large, then the rate for some living or future generations will have to increase substantially and may harm their incentives to work, save, and invest. Hence, a large generational imbalance points to the potential for a weaker future economic performance. Conversely, if an imbalance implies that the future rate will be lower than the current one, someone must pay less to keep the government's net wealth from growing so big that government owns all of the nation's assets. Generational accounting can estimate the sizes of policy changes that would restore sustainability and generational balance.

Section I reports generational accounts and the associated lifetime net tax rates for the United States. The results suggest that U.S. fiscal policy is generationally imbalanced. If living generations pay net taxes as scheduled, future generations will have to pay a lifetime net tax rate far exceeding that of current newborns49.2 versus 28.6 percent, an arithmetic difference of 20.6 percentage points.

Ordinarily, generational accounting does not estimate by age who benefits from prospective purchases, only who pays for them with their net taxes. In this study, however, we also calculate an alternative set of accounts that assign to each living generation the benefit from its share of government spending on education. The recalculated accounts show a similar arithmetic difference in lifetime net tax rates.

These results depend on a "reference" scenario for fiscal policy, the economy, and the population. The reference policy used here cuts the deficit, splitting the reduction evenly between Medicare and discretionary spending and balancing the budget in the years from 2002 through 2007. After that, however, it allows the deficit to widen, reflecting an aging population, slowing labor force growth, and rising per capita medical costs. Through 2070, the reference scenario depends on three factors: the federal tax and spending schedule, the "no-feedback" economic projection of the Congressional Budget Office (CBO), and the Social Security Administration's (SSA) intermediate population projection. ${ }^{4}$ Beyond 2070 , the reference scenario extends those fiscal, economic, and demographic projections by the methods described below.

The reference scenario does not include the recent budget reconciliation package (the Balanced Budget Act of 1997 and the Taxpayer Relief Act of 1997), because long-term projections under that package are not yet available. Other things equal, the results under the reference scenario should roughly correspond to those under the reconciliation package, since both policies cut base spending on health care and other (non-Social Security) programs in about the same proportions. However, the most recent budget projections yield more than just midterm budget balance; they show a small surplus in 2002, which rises to about 0.7 percent of GDP in 2007 (CBO [1997c]). Therefore, the current fiscal stance is likely to produce a smaller generational imbalance than the one based on the reference policy. Even so, in contrast to the accounts reported earlier, the reference scenario implies a sharp decline in the degree of generational imbalance. ${ }^{5}$

4 See SSA (1997) and CBO (1997a, chapter 1, 1997b).

5 The results here update those in Auerbach, Gokhale, and Kotlikoff (1995). 
Section II details the reasons for that decline, which occurred largely because per capita costs for medical programs have recently grown more slowly than expected. Section III reports the amounts by which generational accounts change when we alter the assumptions for population growth, government spending, and economic growth or discount rates. Generational accounts move into or near balance under some of these assumptions, but remain imbalanced under most.

Section IV considers hypothetical policy actions that achieve generational balance by changing the reference policy's schedule for purchases or for the net taxes that living generations will pay. The required size of such a change depends on whether it cuts prospective purchases or raises prospective net taxes for current generations. For instance, under the reference assumptions, balance could now be restored by proportional cuts of 15.4 percent in purchases or 18.5 percent in transfers, or by an increase of 8.9 percent in taxes. (The changes differ because the programs involve different initial dollar amounts and because the effects of the changes depend on both how fast the programs expand and which generations are most affected.) Although we examine these policies only as examples of the magnitude of the imbalance, it is clear that the longer the status quo persists, the more difficult it will be to restore generational balance. Section $\mathrm{V}$ concludes the paper.

\section{The Generational Stance of U.S. Fiscal Policy}

\section{Intertemporal Government Budget Constraint}

The intertemporal government budget constraint is expressed as

$$
\mathrm{PVG}_{\mathrm{t}}=\mathrm{NWG}_{\mathrm{t}}+\mathrm{PVL}_{\mathrm{t}}+\mathrm{PVF}_{\mathrm{t}}
$$

where $\mathrm{PVG}_{\mathrm{t}}$ is the present value of government purchases, $\mathrm{NWG}_{t}$ is the current value of government financial net wealth, $\mathrm{PVL}_{t}$ is the total present value of net taxes that living generations will pay over the rest of their lives, and $\mathrm{PVF}_{\mathrm{t}}$ is the residual fiscal burden that future generations must bear., 6

To calculate these values for a base case, we assume the following: 1) the real discount rate is 6 percent, 2) labor productivity growth through 2070 is given by the reference scenario; beyond
2070, it is assumed to be 1.2 percent per year (its average annual growth rate for most of the reference scenario), 3) aggregate taxes, transfers, and purchases through 2070 are given by the reference projection; beyond 2070, they are assumed to grow at a rate consistent with per capita growth at the same rate as labor productivity, and 4) the population through 2070 is the SSA's intermediate projection; from 2070 through 2200, we extend that projection by assuming that fertility, mortality, and net immigration rates remain at their 2070 values; beyond 2200 , we assume that the size and the age composition of the population remain fixed.

Under the reference policy and the assumptions mentioned earlier, $\mathrm{PVG}_{\mathrm{t}}$ equals $\$ 29.4$ trillion, and $\mathrm{NWG}_{\mathrm{t}}$ (calculated as the algebraic sum of past real government surpluses) amounts to - \$2.1 trillion. Loosely, $\mathrm{NWG}_{t}$ is the negative of net public debt, $\mathrm{NDG}_{\mathrm{t}}$. $\mathrm{PVL}_{\mathrm{t}}$ equals $\$ 22.1$ trillion, and $\mathrm{PVF}_{\mathrm{t}}$ is $\$ 9.4$ trillion. ${ }^{8}$

It is $\mathrm{PVF}_{\mathrm{t}}$, rather than $\mathrm{NDG}_{\mathrm{t}}$, that more meaningfully reflects the fiscal burden that the reference policy imposes on future generations. $\mathrm{NDG}_{\mathrm{t}}$ includes only the explicit legal obligations of U.S. governments, not their implicit obligations. For example, the current debt ignores the unfunded liabilities of Medicare, Social Security, and government retirement programs. Outlays for these programs will accelerate in the future as the baby boom generations retire and as the costs of health care programs mount. In contrast to the debt, $\mathrm{PVF}_{\mathrm{t}}$ includes all prospective govemment liabilities, implicit as well as explicit. We calculate that $\mathrm{PVF}_{\mathrm{t}}$ is more than four times as large as $\mathrm{NDG}_{\mathrm{t}}-\$ 9.4$ trillion versus $\$ 2.1$ trillion.

\section{Generational Accounts}

A generational account is the present value of the per capita net taxes that a generation will

6 The constraint includes all debt, taxes, transfers, and purchases at every level of government. Unlike the National Income and Product Accounts, generational accounting treats spending on medical, disability, and retirement benefits for veterans and government workers as purchases (payment for past services), rather than as transfers. For an explanation of how generational accounts treat taxes, transfers, and purchases, see Auerbach, Gokhale, and Kotlikoff (1991); for a description of how generational accounting implements the calculations, see the Appendix.

- $7 \quad N W G_{t}$ excludes the value of tangible government assets, and $P V G$ excludes the service flows of those assets. If $N W G$ included the assets, $P V G_{t}$ would have to include the service flows. Because (in equilibrium) the assets and their service flows are equal in present value, their inclusion would not affect the balance in equation (1).

8 All dollar figures are reported in constant 1995 dollars. For details about the calculations, see the Appendix. 


\title{
T A B L E 1
}

\author{
Composition of Male \\ Generational Accounts under \\ Reference Assumptions ${ }^{a}$
}

Tax Payments

\begin{tabular}{|c|c|c|c|c|c|c|c|c|}
\hline \multirow[b]{2}{*}{$\begin{array}{l}\text { Generation's } \\
\text { Age in } 1995\end{array}$} & \multirow[b]{2}{*}{$\begin{array}{c}\text { Net Tax } \\
\text { Payment }\end{array}$} & & \\
\hline & & $\begin{array}{l}\text { Labor } \\
\text { Income }\end{array}$ & $\begin{array}{l}\text { Capital } \\
\text { Income }\end{array}$ & Payroll & Other $\mathbf{b}$ & $\begin{array}{c}\text { Social } \\
\text { Security }\end{array}$ & Health & Other \\
\hline 0 & 77.4 & 33.5 & 9.0 & 34.3 & 31.5 & 7.2 & 19.6 & 4.2 \\
\hline 5 & 95.7 & 41.6 & 11.2 & 42.8 & 36.6 & 8.8 & 22.5 & 5.2 \\
\hline 10 & 119.5 & 52.1 & 14.3 & 53.9 & 42.5 & 10.6 & 26.3 & 6.5 \\
\hline 15 & 149.1 & 65.1 & 18.1 & 67.8 & 48.6 & 12.1 & 30.4 & 8.1 \\
\hline 20 & 182.2 & 79.5 & 23.5 & 83.6 & 53.4 & 13.7 & 34.4 & 9.7 \\
\hline 25 & 196.2 & 86.0 & 27.9 & 90.6 & 53.5 & 16.4 & 35.4 & 10.1 \\
\hline 30 & 196.8 & 86.3 & 33.7 & 90.2 & 52.7 & 19.9 & 36.4 & 9.8 \\
\hline 35 & 189.0 & 82.9 & 40.7 & 86.0 & 51.4 & 24.6 & 38.2 & 9.2 \\
\hline 40 & 171.2 & 76.0 & 46.6 & 78.6 & 50.4 & 30.8 & 40.9 & 8.7 \\
\hline 45 & 139.2 & 65.1 & 50.2 & 67.4 & 47.7 & 38.8 & 44.3 & 8.1 \\
\hline 50 & 93.7 & 50.8 & 51.3 & 52.9 & 43.7 & 49.3 & 48.0 & 7.6 \\
\hline 55 & 37.5 & 34.6 & 49.7 & 36.3 & 38.7 & 62.8 & 52.0 & 7.0 \\
\hline 60 & -25.5 & 18.6 & 46.3 & 19.5 & 32.9 & 80.1 & 56.5 & 6.3 \\
\hline 65 & -77.7 & 7.4 & 41.2 & 7.5 & 27.5 & 91.8 & 63.8 & 5.7 \\
\hline 70 & -89.2 & 3.2 & 33.0 & 3.3 & 22.2 & 85.0 & 60.9 & 5.1 \\
\hline 75 & -87.9 & 1.6 & 22.4 & 1.7 & 16.9 & 71.7 & 54.5 & 4.2 \\
\hline 80 & -77.2 & 0.9 & 11.2 & 1.0 & 11.9 & 54.8 & 44.4 & 3.1 \\
\hline 85 & -68.3 & 0.7 & 0.0 & 0.7 & 8.0 & 42.6 & 32.9 & 2.1 \\
\hline 90 & -53.8 & 0.5 & 0.0 & 0.5 & 6.3 & 33.7 & 25.9 & 1.7 \\
\hline $\begin{array}{l}\text { Future } \\
\text { generations }\end{array}$ & 134.6 & - & - & - & - & - & - & - \\
\hline $\begin{array}{l}\text { Percent } \\
\text { difference }\end{array}$ & 71.9 & - & - & - & - & - & - & - \\
\hline
\end{tabular}

a. Present value in thousands of 1995 dollars.

b. Includes excise taxes, other indirect taxes, and property taxes.

c. Federal Old-Age and Survivors Insurance and Disability Insurance Trust Funds.

d. Generations born in 1996 and thereafter.

NOTE: The net tax payment represents a present value as of 1996. The percentage difference between the net tax payments of future generations and current newboms is calculated after adjustment for economic growth (see text).

SOURCE: Authors' calculations.

pay for the rest of its life under the assumed fiscal policy. (Generational accounting defines a generation by sex and year of birth.) To obtain each generation's prospective per capita values through 2070, generational accounting first distributes among the generations the reference projections for aggregate taxes and transfers. The distribution assumes that the current ratios of per capita taxes and transfers by age and sex remain fixed. For instance, in a given year, 50year-old women always pay 38 percent as much in per capita payroll taxes as do 40-yearold men.9,10 Beyond 2070, generational accounting assumes that the per capita amount of each type of tax or transfer by age or sex grows at the same rate as labor productivity. The resulting streams of per capita net taxes are actuarially discounted to the base year in order to calculate the generational account for each living generation. (The base year in this case is 1995, the latest year for which we have the ratios of per capita taxes and transfers by age and sex.)

As tables 1 and 2 show, generational accounts follow a life-cycle pattern. Young generations at or near working age will pay a significant amount of taxes for several years long before they retire and collect Social Security

9 The ratios are estimated from official survey data. For details of the procedure, see Auerbach, Gokhale, and Kotlikoff (1991); for a description of the respective ratios of per capita net payments by age and sex, see CBO (1995), pp. 7-8.

10 For Social Security and government retirement programs, the generational accounts shown here reflect the way in which productivity growth feeds gradually into benefits under current schedules. Thus, the ratios of per capita benefits by age and sex for these programs need not remain fixed. See CBO (1997b). 


\section{T A B L E 2}

Composition of Female

Generational Accounts under

Reference Assumptions ${ }^{a}$

Tax Payments

Transfer Receipts

\begin{tabular}{|c|c|c|c|c|c|c|c|c|}
\hline $\begin{array}{l}\text { Generation's } \\
\text { Age in } 1995\end{array}$ & $\begin{array}{c}\text { Net Tax } \\
\text { Payment }\end{array}$ & $\begin{array}{c}\text { Labor } \\
\text { Income }\end{array}$ & $\begin{array}{c}\text { Capital } \\
\text { Income }\end{array}$ & Payroll & Other $^{\mathbf{b}}$ & $\begin{array}{c}\text { Social } \\
\text { Security }\end{array}$ & Health & Other \\
\hline 0 & 51.9 & 19.4 & 9.5 & 20.9 & 30.4 & 6.8 & 14.8 & 6.8 \\
\hline 5 & 63.4 & 24.1 & 11.9 & 26.1 & 35.2 & 8.3 & 16.9 & 8.5 \\
\hline 10 & 78.1 & 30.2 & 15.1 & 32.9 & 40.5 & 10.0 & 19.9 & 10.6 \\
\hline 15 & 95.7 & 37.7 & 19.3 & 41.3 & 45.6 & 11.3 & 23.4 & 13.5 \\
\hline 20 & 115.0 & 45.7 & 24.8 & 50.7 & 49.8 & 12.7 & 26.6 & 16.8 \\
\hline 25 & 122.6 & 48.1 & 30.3 & 53.7 & 50.4 & 15.3 & 28.9 & 15.7 \\
\hline 30 & 120.7 & 46.2 & 36.2 & 51.6 & 50.1 & 18.6 & 31.7 & 13.2 \\
\hline 35 & 113.8 & 42.8 & 42.3 & 47.9 & 49.8 & 23.0 & 35.2 & 10.8 \\
\hline 40 & 99.0 & 38.2 & 46.3 & 43.0 & 48.6 & 28.8 & 39.6 & 8.7 \\
\hline 45 & 72.8 & 31.6 & 47.7 & 35.7 & 46.2 & 36.5 & 45.0 & 7.0 \\
\hline 50 & 37.4 & 23.6 & 46.8 & 26.9 & 42.3 & 46.9 & 49.5 & 5.6 \\
\hline 55 & -5.2 & 15.0 & 44.8 & 17.2 & 37.6 & 60.6 & 54.5 & 4.8 \\
\hline 60 & -52.0 & 7.6 & 41.6 & 8.7 & 32.4 & 78.6 & 59.5 & 4.2 \\
\hline 65 & -91.2 & 2.7 & 35.6 & 3.1 & 27.1 & 89.3 & 66.5 & 3.8 \\
\hline 70 & -101.0 & 1.0 & 25.3 & 1.2 & 22.2 & 83.4 & 63.9 & 3.4 \\
\hline 75 & -101.0 & 0.5 & 14.1 & 0.6 & 16.9 & 71.6 & 58.5 & 2.9 \\
\hline 80 & -90.2 & 0.3 & 5.3 & 0.3 & 12.4 & 57.2 & 48.8 & 2.4 \\
\hline 85 & -73.5 & 0.1 & 0.0 & 0.1 & 9.4 & 43.5 & 37.8 & 1.9 \\
\hline 90 & -55.8 & 0.1 & 0.0 & 0.1 & 7.2 & 33.2 & 28.5 & 1.5 \\
\hline \multicolumn{9}{|l|}{ Future } \\
\hline generations $^{\mathrm{d}}$ & 90.2 & - & - & - & - & - & - & - \\
\hline \multicolumn{9}{|l|}{ Percent } \\
\hline difference & 71.9 & - & - & - & - & - & - & - \\
\hline
\end{tabular}

a. Present value in thousands of 1995 dollars.

b. Includes excise taxes, other indirect taxes, and property taxes.

c. Federal Old-Age and Survivors Insurance and Disability Insurance Trust Funds.

d. Generations born in 1996 and thereafter.

NOTE: The net tax payment represents a present value as of 1996. The percentage difference between the net tax payments of future generations and current newborns is calculated after adjustment for economic growth (see text).

SOURCE: Authors' calculations.

and Medicare benefits. Hence, their generational accounts are positive and high. By contrast, older generations in or near retirement will pay low taxes and receive high transfers for most of their remaining years. Thus, their generational accounts are negative.

The generational accounts for women of any age are lower (or more negative) than those for men of the same age. On average, women pay lower taxes because they are less likely to work in the marketplace, and earn less when they do. Moreover, they live longer and often receive payments as widows on their husbands' accounts. Therefore, relative to their earnings, they receive more in transfers, especially for medical care and Social Security.
Generational accounts compare on the same lifetime basis the net payments of current newborns (those born in 1995) and future generations (those born later). That is, the accounts show the present value of per capita net taxes that each group will pay over its entire life. How do their accounts compare? Under the reference policy, the generational account for a 1995 newborn is $\$ 77,400$ for a male and $\$ 51,900$ for a female. As mentioned earlier, the residual burden on future generations is $\$ 9.4$ trillion, but there is no way to know how they would share that burden. To get around this problem, generational accounting assumes that future generations split the burden equally on a growth-adjusted basis. As noted, this assumption amounts to specifying that males 


\section{T A B L E 3}

Lifetime Net Tax Rates

under Reference Assumptions ${ }^{a}$

\begin{tabular}{|c|c|c|c|}
\hline \multirow[b]{2}{*}{$\begin{array}{l}\text { Generation's } \\
\text { Year of Birth }\end{array}$} & \multirow[b]{2}{*}{$\begin{array}{c}\text { Net } \\
\text { Tax Rate }\end{array}$} & \multicolumn{2}{|c|}{ Components of Net Tax } \\
\hline & & $\begin{array}{c}\text { Gross } \\
\text { Rate }\end{array}$ & $\begin{array}{c}\text { Transfer } \\
\text { Rate }\end{array}$ \\
\hline 1900 & 23.9 & 28.0 & 4.0 \\
\hline 1910 & 27.5 & 33.4 & 6.0 \\
\hline 1920 & 29.6 & 36.4 & 6.7 \\
\hline 1930 & 31.3 & 38.4 & 7.1 \\
\hline 1940 & 32.5 & 40.3 & 7.8 \\
\hline 1950 & 33.4 & 43.0 & 9.5 \\
\hline 1960 & 33.3 & 44.1 & 10.8 \\
\hline 1970 & 32.4 & 44.3 & 11.9 \\
\hline 1980 & 30.8 & 43.0 & 12.2 \\
\hline 1990 & 29.3 & 42.1 & 12.8 \\
\hline 1995 & 28.6 & 41.7 & 13.1 \\
\hline $\begin{array}{l}\text { Future } \\
\text { generations } \mathrm{b}\end{array}$ & 49.2 & - & - \\
\hline
\end{tabular}

a. Percent.

b. Generations born in 1996 and thereafter.

NOTE: Numbers may not sum because of rounding.

SOURCE: Authors' calculations.

and females born in each future year will pay combined lifetime net taxes at a uniform rate. ${ }^{11}$ Given this assumption, the reference policy implies that males born in 1996 will pay an average of $\$ 134,600$ (in present value as of 1996), while females will pay an average of $\$ 90,200$. These payments are larger than the corresponding payments of current newborns, indicating that the reference policy is out of generational balance.

\section{Lifetime Net Tax Rates}

So far, it has been legitimate to compare directly only the generational accounts of current newborns and future generations. These accounts give each group's net payment over its entire life. Other generations, however, are at varying stages of their life cycles. Thus, their accounts are not directly comparable because their net payments are stated only over their remaining lives. For instance, the generational account of a 40-year-old man is higher than that of a 50-yearold man, because the 40-year-old has 10 more years of taxes to pay and is 10 years farther from receiving Social Security and Medicare benefits. But the accounts cannot say whether the 40-year-old paid net taxes in the past at the same effective rate as the 50-year-old when he was 40 . Nor do the accounts state how a 60year-old woman's current negative account compares with her past net taxes.

To compare everyone on the same basis, generational accounting calculates the effective rate at which each generation pays net taxes over its entire life - its lifetime net tax rate. The method first estimates each generation's past net taxes (in addition to its prospective net taxes) to find its per capita lifetime net taxes. Those per capita net taxes are then discounted to the year in which the generation was born in order to find its generational account at birth. Similarly, the procedure estimates each generation's per capita lifetime labor income and finds its present value at birth. The generational account at birth is then divided by the present value at birth of per capita lifetime labor income to yield the generation's lifetime net tax rate. ${ }^{12}$ A lifetime net tax rate compares all generations on the same basis - the effective share of labor income that its members will pay in net taxes over their entire lives.

As table 3 shows, the lifetime net tax rate for successive generations has both risen and fallen over the century. It started at 23.9 percent for people bom in 1900, climbed to 33.4 percent for those born in 1950, then fell to 28.6 percent for those born in 1995. ${ }^{13}$ The rise in the rate for successive generations through 1950 coincided with a similar increase in the share of output devoted to government purchases. The decline in the rate for successive generations since 1950 stems mostly from three factors: longer life expectancies, a decline in the effective rate of excise taxes, and-most

11 See the Appendix for details. The calculation assumes that labor productivity (and hence, eventually, per capita income) grows each year at rate $g$. In that case, an equal growth-adjusted share of the burden means that the per capita net payment of each future generation is $(1+g)$ times that of its immediate predecessor. If males born in 1996 pay $\$ Y$ each, then males born in 1997 pay $\$ Y(1+g)$ each, males born in 1998 pay $\$ Y(1+g)^{2}$ each, and so forth. (Generational accounting gives those per capita net payments in present value as of the generation's birth year.) Similarly, if females born in 1996 pay $\$ X$ each, then females born in 1997 pay $\$ X(1+g)$ each, and so on. This procedure amounts to assuming that all future males pay lifetime net taxes at a uniform rate: Their lifetime net taxes grow generation by generation at the same rate as their lifetime incomes. Future females also pay lifetime net taxes at a uniform rate, but it is lower than the rate for males.

12 For a discussion of the reasons that generational accounting uses lifetime income from labor, rather than from both capital and labor, see the Appendix.

13 These rates are ratios of population-weighted net taxes to population-weighted labor incomes. 


\title{
T A B L E 4
}

\author{
Composition of Male \\ Generational Accounts under \\ Reference Assumptions: \\ Benefits of Education Spending \\ Distributed by Age and Sex
}

\begin{tabular}{|c|c|c|c|c|c|c|c|c|c|}
\hline \multirow[b]{2}{*}{$\begin{array}{l}\text { Generation's } \\
\text { Age in } 1995\end{array}$} & \multirow[b]{2}{*}{$\begin{array}{l}\text { Net Tax } \\
\text { Payment }\end{array}$} & \multicolumn{4}{|c|}{ Tax Payments } & \multicolumn{4}{|c|}{ Transfer Receipts } \\
\hline & & $\begin{array}{l}\text { Labor } \\
\text { Income }\end{array}$ & $\begin{array}{l}\text { Capital } \\
\text { Income }\end{array}$ & Payroll & Other $^{\mathbf{b}}$ & $\begin{array}{c}\text { Social } \\
\text { Securityc }\end{array}$ & Health & Education & Other \\
\hline 0 & 25.7 & 33.5 & 9.0 & 34.3 & 31.5 & 7.2 & 19.6 & 51.7 & 4.2 \\
\hline 5 & 33.1 & 41.6 & 11.2 & 42.8 & 36.6 & 8.8 & 22.5 & 62.6 & 5.2 \\
\hline 10 & 71.4 & 52.1 & 14.3 & 53.9 & 42.5 & 10.6 & 26.3 & 48.1 & 6.5 \\
\hline 15 & 120.1 & 65.1 & 18.1 & 67.8 & 48.6 & 12.1 & 30.4 & 28.9 & 8.1 \\
\hline 20 & 172.7 & 79.5 & 23.5 & 83.6 & 53.4 & 13.7 & 34.4 & 9.5 & 9.7 \\
\hline 25 & 193.3 & 86.0 & 27.9 & 90.6 & 53.5 & 16.4 & 35.4 & 2.9 & 10.1 \\
\hline 30 & 195.1 & 86.3 & 33.7 & 90.2 & 52.7 & 19.9 & 36.4 & 1.7 & 9.8 \\
\hline 35 & 187.8 & 82.9 & 40.7 & 86.0 & 51.4 & 24.6 & 38.2 & 1.2 & 9.2 \\
\hline 40 & 170.4 & 76.0 & 46.6 & 78.6 & 50.4 & 30.8 & 40.9 & 0.7 & 8.7 \\
\hline 45 & 138.7 & 65.1 & 50.2 & 67.4 & 47.7 & 38.8 & 44.3 & 0.5 & 8.1 \\
\hline 50 & 93.6 & 50.8 & 51.3 & 52.9 & 43.7 & 49.3 & 48.0 & 0.2 & 7.6 \\
\hline 55 & 37.3 & 34.6 & 49.7 & 36.3 & 38.7 & 62.8 & 52.0 & 0.1 & 7.0 \\
\hline 60 & -25.6 & 18.6 & 46.3 & 19.5 & 32.9 & 80.1 & 56.5 & 0.1 & 6.3 \\
\hline 65 & -77.7 & 7.4 & 41.2 & 7.5 & 27.5 & 91.8 & 63.8 & 0.0 & 5.7 \\
\hline 70 & -89.2 & 3.2 & 33.0 & 3.3 & 22.2 & 85.0 & 60.9 & 0.0 & 5.1 \\
\hline 75 & -87.9 & 1.6 & 22.4 & 1.7 & 16.9 & 71.7 & 54.5 & 0.0 & 4.2 \\
\hline 80 & -77.3 & 0.9 & 11.2 & 1.0 & 11.9 & 54.8 & 44.4 & 0.0 & 3.1 \\
\hline 85 & -68.3 & 0.7 & 0.0 & 0.7 & 8.0 & 42.6 & 32.9 & 0.0 & 2.1 \\
\hline 90 & -53.8 & 0.5 & 0.0 & 0.5 & 6.3 & 33.7 & 25.9 & 0.0 & 1.7 \\
\hline Future & & & & & & & & & \\
\hline generations $^{\mathrm{d}}$ & 114.3 & - & - & - & - & - & - & - & - \\
\hline Percent & & & & & & & & & \\
\hline difference & 340.3 & - & - & - & - & - & - & - & - \\
\hline
\end{tabular}

a. Present value in thousands of 1995 dollars.

b. Includes excise taxes, other indirect taxes, and property taxes.

c. Federal Old-Age and Survivors Insurance and Disability Insurance Trust Funds.

d. Generations born in 1996 and thereafter.

NOTE: The net tax payment represents a present value as of 1996. The percentage difference between the net tax payments of future generations and current newborns is calculated after adjustment for economic growth (see text).

SOURCE: Authors' calculations.

important- the rapid growth in per capita health care and Social Security transfers that began in the 1960s. ${ }^{14}$

The results shown in table 3 indicate that the reference policy is unsustainable. Either prospective purchases must fall or the effective schedule at which people pay net taxes must rise - if not for current generations, then for future ones. If current generations pay net taxes as scheduled by the reference policy, current newborns will pay lifetime net taxes of 28.6 percent, and future generations will pay 49.2 percent. $^{15}$

We can use these lifetime net tax rates to quantify the notion of generational imbalance. The degree of such imbalance is given as a percentage, namely, the arithmetic difference in the lifetime net tax rates of future generations and current newboms as a fraction of the lifetime net tax rate of current newborns. Thus, the degree of imbalance under the reference scenario is 72 percent (the difference between 49.2 and 28.6 as a percentage of 28.6). A degree of zero indicates generational balance, while a

14 Excise taxes affect a generational account at birth more than do other taxes. Generational accounting prorates excise taxes among all family members, including children. Therefore, a decline in the excise tax lowers the estimated taxes that a child pays early in life. An earlier payment has a higher present value at birth than does the same payment at a later time. Hence, a cut in the excise tax lowers lifetime net tax rates by more than does a cut in another tax that reduces current revenue by the same amount.

15 These figures do not represent a forecast. They project only what would happen if the reference policy applied to current generations for the rest of their lives. 


\section{T A B L E 5}

\section{Composition of Female \\ Generational Accounts under \\ Reference Assumptions: \\ Benefits of Education Spending \\ Distributed by Age and Sex ${ }^{a}$}

Tax Payments

\begin{tabular}{|c|c|c|c|c|c|c|c|c|c|}
\hline \multirow[b]{2}{*}{$\begin{array}{l}\text { Generation's } \\
\text { Age in } 1995\end{array}$} & \multirow[b]{2}{*}{$\begin{array}{c}\text { Net Tax } \\
\text { Payment }\end{array}$} & \multicolumn{4}{|c|}{ Tax Payments } & \multicolumn{4}{|c|}{ Transfer Receipts } \\
\hline & & $\begin{array}{l}\text { Labor } \\
\text { Income }\end{array}$ & $\begin{array}{l}\text { Capital } \\
\text { Income }\end{array}$ & Payroll & Otherb & $\begin{array}{c}\text { Social } \\
\text { Securityc }\end{array}$ & Health & Education & Other \\
\hline 0 & 0.1 & 19.4 & 9.5 & 20.9 & 30.4 & 6.8 & 14.8 & 51.8 & 6.8 \\
\hline 5 & 0.8 & 24.1 & 11.9 & 26.1 & 35.2 & 8.3 & 16.9 & 62.6 & 8.5 \\
\hline 10 & 29.9 & 30.2 & 15.1 & 32.9 & 40.5 & 10.0 & 19.9 & 48.2 & 10.6 \\
\hline 15 & 66.8 & 37.7 & 19.3 & 41.3 & 45.6 & 11.3 & 23.4 & 28.9 & 13.5 \\
\hline 20 & 105.5 & 45.7 & 24.8 & 50.7 & 49.8 & 12.7 & 26.6 & 9.5 & 16.8 \\
\hline 25 & 119.7 & 48.1 & 30.3 & 53.7 & 50.4 & 15.3 & 28.9 & 3.0 & 15.7 \\
\hline 30 & 119.0 & 46.2 & 36.2 & 51.6 & 50.1 & 18.6 & 31.7 & 1.7 & 13.2 \\
\hline 35 & 112.6 & 42.8 & 42.3 & 47.9 & 49.8 & 23.0 & 35.2 & 1.2 & 10.8 \\
\hline 40 & 98.3 & 38.2 & 46.3 & 43.0 & 48.6 & 28.8 & 39.6 & 0.8 & 8.7 \\
\hline 45 & 72.2 & 31.6 & 47.7 & 35.7 & 46.2 & 36.5 & 45.0 & 0.6 & 7.0 \\
\hline 50 & 37.3 & 23.6 & 46.8 & 26.9 & 42.3 & 46.9 & 49.5 & 0.2 & 5.6 \\
\hline 55 & -5.3 & 15.0 & 44.8 & 17.2 & 37.6 & 60.6 & 54.5 & 0.2 & 4.8 \\
\hline 60 & -52.1 & 7.6 & 41.6 & 8.7 & 32.4 & 78.6 & 59.5 & 0.1 & 4.2 \\
\hline 65 & -91.2 & 2.7 & 35.6 & 3.1 & 27.1 & 89.3 & 66.5 & 0.0 & 3.8 \\
\hline 70 & -101.1 & 1.0 & 25.3 & 1.2 & 22.2 & 83.4 & 63.9 & 0.0 & 3.4 \\
\hline 75 & -101.0 & 0.5 & 14.1 & 0.6 & 16.9 & 71.6 & 58.5 & 0.0 & 2.9 \\
\hline 80 & -90.2 & 0.3 & 5.3 & 0.3 & 12.4 & 57.2 & 48.8 & 0.0 & 2.4 \\
\hline 85 & -73.6 & 0.1 & 0.0 & 0.1 & 9.4 & 43.5 & 37.8 & 0.0 & 1.9 \\
\hline 90 & -55.8 & 0.1 & 0.0 & 0.1 & 7.2 & 33.2 & 28.5 & 0.0 & 1.5 \\
\hline Future & & & & & & & & & \\
\hline generations $^{\mathrm{d}}$ & 0.3 & - & - & - & - & - & - & - & - \\
\hline $\begin{array}{l}\text { Percent } \\
\text { difference }\end{array}$ & 328.3 & - & - & - & - & - & - & - & - \\
\hline
\end{tabular}

a. Present value in thousands of 1995 dollars.

b. Includes excise taxes, other indirect taxes, and property taxes.

c. Federal Old-Age and Survivors Insurance and Disability Insurance Trust Funds.

d. Generations born in 1996 and thereafter.

NOTE: The net tax payment represents a present value as of 1996. The percentage difference between the net tax payments of future generations and current newborns is calculated after adjustment for economic growth (see text).

SOURCE: Authors' calculations.

negative degree indicates an imbalance in favor of the future.

\section{The Benefits of \\ Government Spending \\ on Education by \\ Age and Sex}

How would this outcome differ if the accounts assigned, by age, the benefits that living generations receive from government purchases? It is impossible to assign the benefits from many purchases, such as those for defense or administration, because they generate public services that apply equally to everyone. ${ }^{16}$ Arguably, however, we can estimate by age the per capita benefits from one category of purchases- education spending (now about one-fifth of total government purchases). Below, we recalculate the generational accounts by treating all prospective government spending for education as a transfer rather than a purchase, then distributing that spending by age. ${ }^{17}$

The recalculation substantially lowers the lifetime net taxes of those under age 25 (see tables 4 and 5), since they receive most of the benefits from such spending. The recalculated generational account for males born in 1995 is

16 Beyond 2070 (the end of the reference projection), generational accounting prorates each year's per capita cost of such purchases to everyone alive in that year. However, the method is used only to estimate total prospective purchases, not to try to assign the benefits of those purchases by age.

17 Data used in the calculation are from the U.S. Department of Education (1997). 


\section{F I G U R E 1}

\section{Comparison of Projected Budget}

\section{Aggregates: GA1993 Versus GA1995}
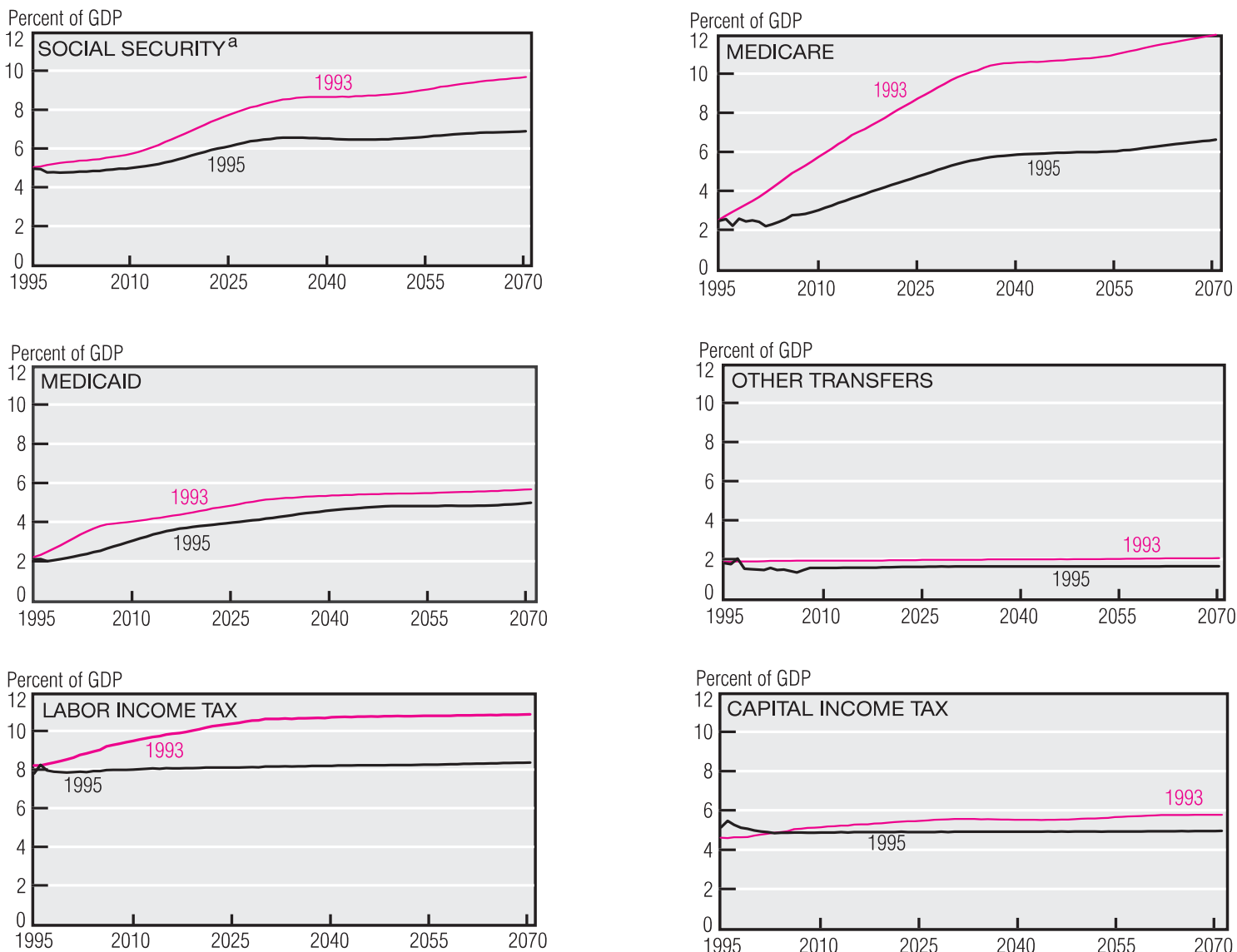

Percent of GDP
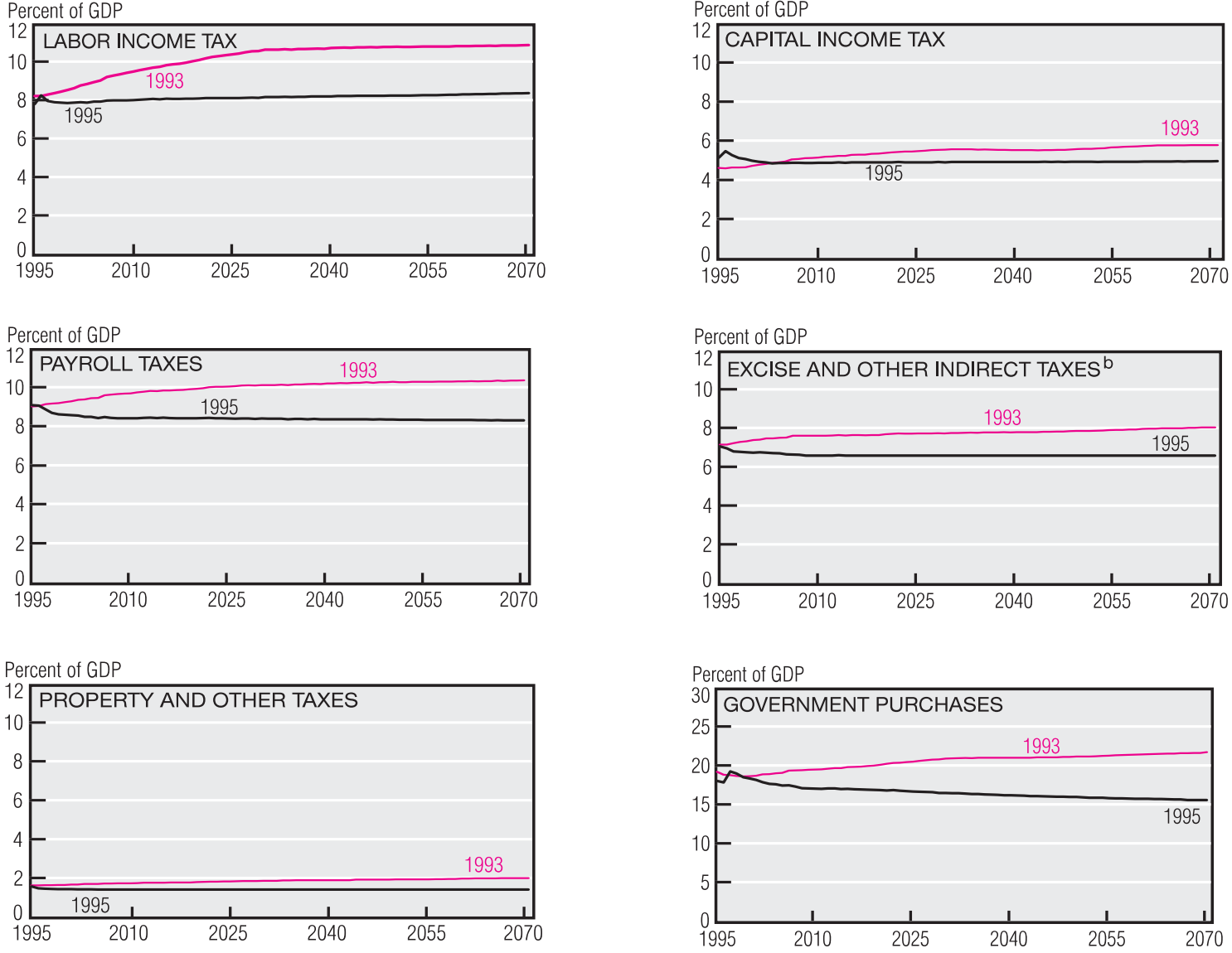

a. Federal Old-Age and Survivors Insurance and Disability Insurance Trust Funds.

b. Excludes property taxes.

SOURCES: Congressional Budget Office; Office of Management and Budget; and authors' calculations. 


\section{T A B L E 6}

Generational Accounts, 1993

Versus 1995: Cumulative Impact

of Updating Demographic and

Fiscal Projections

\begin{tabular}{|c|c|c|c|}
\hline & \multicolumn{2}{|c|}{ Lifetime Net Tax Rates ${ }^{\mathrm{a}}$} & \multirow[b]{2}{*}{$\begin{array}{c}\text { Percent } \\
\text { Difference }\end{array}$} \\
\hline & Newborns & $\begin{array}{c}\text { Future } \\
\text { Generations }^{\mathbf{b}}\end{array}$ & \\
\hline 1993 accounts & 34.2 & 84.4 & 147.1 \\
\hline $\begin{array}{l}\text { Freeze } 1993 \\
\text { policy for two years }\end{array}$ & 34.1 & 87.4 & 156.0 \\
\hline $\begin{array}{l}\text { Update population } \\
\text { projections }\end{array}$ & 33.6 & 85.3 & 154.1 \\
\hline Fiscal projections & & & \\
\hline $\begin{array}{l}\text { Transfers } \\
\text { Social Security } \\
\text { Medicare and Medicaid } \\
\text { Other }\end{array}$ & $\begin{array}{l}34.6 \\
36.9 \\
37.7\end{array}$ & $\begin{array}{l}76.4 \\
46.9 \\
44.5\end{array}$ & $\begin{array}{r}121.2 \\
27.1 \\
18.1\end{array}$ \\
\hline $\begin{array}{l}\text { Government purchases } \\
\text { Federal } \\
\text { State and local }\end{array}$ & $\begin{array}{l}37.7 \\
37.7\end{array}$ & $\begin{array}{l}46.0 \\
21.5\end{array}$ & $\begin{array}{r}22.0 \\
-42.9\end{array}$ \\
\hline Government wealth & 37.7 & 20.8 & -44.8 \\
\hline $\begin{array}{l}\text { Taxes } \\
\text { Income }^{\mathrm{d}}\end{array}$ & 33.6 & 32.5 & $\begin{array}{r}-3.2 \\
305\end{array}$ \\
\hline $\begin{array}{l}\text { Excise and } \\
\text { other indirect } \\
\text { Property and other }\end{array}$ & $\begin{array}{l}29.1 \\
28.7\end{array}$ & $\begin{array}{l}46.7 \\
49.3\end{array}$ & $\begin{array}{l}60.4 \\
71.9\end{array}$ \\
\hline Projected labor income & 28.6 & 49.2 & 71.9 \\
\hline 1995 accounts & 28.6 & 49.2 & 71.9 \\
\hline
\end{tabular}

a. Percent.

b. Generations born in 1996 and thereafter.

c. Federal Old-Age and Survivors Insurance and Disability Insurance Trust Funds.

d. Labor and capital.

SOURCE: Authors' calculations.

only $\$ 25,700$, and for females, only $\$ 100$. Thus, education spending cancels much of the net taxes that the rest of the reference policy imposes on the youngest generations.

At the same time, the recalculation also lowers projected purchases (by classifying education outlays as transfers) and thereby reduces the residual burden on future generations. Thus, at 19.2 percentage points, the arithmetic difference in the recalculated lifetime net tax rates of future generations and current newborns is nearly as large as when education outlays are counted as purchases.

\section{The Recent \\ Improvement in the \\ Generational Stance \\ of U.S. Fiscal Policy}

In the past two years, the generational stance of U.S. fiscal policy has improved markedly from that reported in the accounts using 1993 as the base year (GA1993). ${ }^{18,19}$ Given the economic outlook and policy schedule of two years ago, GA1993 estimated that future generations would pay a lifetime net tax rate of 84.4 percent. That rate falls to 49.2 percent under the reference scenario for base year 1995 (GA1995).

What explains this improvement? Most of it stems from lower projected federal spending for medical care, which is now about 10 percent less than what was anticipated two or three years ago. As a result, projected transfer spending for health care is growing from a lower base and remains a smaller share of output (see figure 1). The output shares of other projected taxes, transfers, and government purchases are also below levels seen two years ago. The reason for the lower purchases growth is that projections for state and local government purchases are below GA1993 levels.

We examine the effects of moving from GA1993 to GA1995 by cumulatively updating their underlying assumptions. The change from base year 1993 to 1995 means that the accounts treat people born in 1994 and 1995 as current rather than as future generations. In GA1995, these two generations no longer assume a share of the accumulating residual burden that falls on future generations. Thus, time and compound interest alone raise the lifetime net tax rate on future generations to 87.4 percent (see table 6). The updated projections for population, however, reduce that rate to 85.3 percent. As noted, the newer projections for transfers (especially for health care) decrease the rate much farther- more than 40 percentage points. The lower transfers projected for GA1995 entail higher net taxes on living generations and thus a smaller residual burden on future ones. The more recent estimates of current government net wealth and projected purchases by state and local governments lighten that burden still more. By contrast, the lower

18 See Auerbach, Gokhale, and Kotlikoff (1995). The base calculation in 1993 used the OMB's economic and budget projections through 2030. Those projections were extended by assuming that per capita taxes, transfers, and purchases by age and sex grew at the same rate as labor productivity.

19 These calculations, and those that follow, treat government outlays for education as purchases. 


\section{T A B L E 7}

\section{Lifetime Net Tax Rates \\ under Alternative Health \\ Care and Federal \\ Purchase Assumptions ${ }^{a}$}

\begin{tabular}{|c|c|c|c|c|}
\hline $\begin{array}{l}\text { Generation's } \\
\text { Year of } \\
\text { Birth }\end{array}$ & Reference & $\begin{array}{c}\text { Slower } \\
\text { Purchases } \\
\text { Growth }^{\mathbf{b}}\end{array}$ & $\begin{array}{c}\text { Slower } \\
\text { Health } \\
\text { Care } \\
\text { Growthc } \\
\end{array}$ & $\begin{array}{c}\text { Slower } \\
\text { Health Care } \\
\text { and Purchases } \\
\text { Growth }\end{array}$ \\
\hline 1900 & 23.9 & 23.9 & 23.9 & 23.9 \\
\hline 1910 & 27.5 & 27.5 & 27.5 & 27.5 \\
\hline 1920 & 29.6 & 29.6 & 29.7 & 29.7 \\
\hline 1930 & 31.3 & 31.3 & 31.4 & 31.4 \\
\hline 1940 & 32.5 & 32.5 & 32.9 & 32.9 \\
\hline 1950 & 33.4 & 33.4 & 34.0 & 34.0 \\
\hline 1960 & 33.3 & 33.3 & 34.1 & 34.1 \\
\hline 1970 & 32.4 & 32.4 & 33.6 & 33.6 \\
\hline 1980 & 30.8 & 30.8 & 32.4 & 32.4 \\
\hline 1990 & 29.3 & 29.3 & 31.4 & 31.4 \\
\hline 1995 & 28.6 & 28.6 & 30.9 & 30.9 \\
\hline $\begin{array}{l}\text { Future } \\
\text { generations }\end{array}$ & $s^{d} \quad 49.2$ & 44.6 & 38.1 & 33.5 \\
\hline
\end{tabular}

a. Percent.

b. Federal purchases are held constant in real terms after the year 2000.

c. Per capita spending by age for health care grows 2 percentage points slower than under the reference policy through 2003, and expands at the same rate as labor productivity thereafter.

d. Generations born in 1996 and thereafter.

SOURCE: Authors' calculations.

revenue projections of GA1995 reduce the lifetime net tax rate on current newborns and raise that on future generations.

\section{Sensitivity \\ to Alternative \\ Assumptions}

\section{Alternative Projections \\ for Government Purchases \\ and Health Care}

The reported calculations depend on many uncertain or arguable economic and budgetary assumptions. For instance, the reference scenario assumes that real federal discretionary spending falls through 2007 at an average rate of 1.3 percent per year, after that, it grows at the same rate as output. By contrast, the Balanced Budget Act of 1997 limits discretionary spending only through 2002, although subsequent legislation may extend such limits even more..$^{20}$

In the near term, both the Budget Act and the reference policy would intensify the post-Korean War period's secular decline in discretionary spending as a share of output. In the long run, however, it may be difficult to keep such a tight rein on discretionary spending (mostly purchases). For instance, federal nondefense purchases since the 1950s have not changed much as a fraction of output. Moreover, the current replacement schedule for aging defense systems may strain prospective budgets.

Similar uncertainty besets projections of federal mandatory spending (mostly transfers), especially for health care. Through 2007, the reference scenario assumes that real per capita Medicare outlays by age outpace labor productivity by an average of 3.4 percentage points per year. That difference tapers to zero by 2020, after which time Medicare spending is assumed to grow at the same rate as labor productivity. On average through 2020, per capita Medicare spending by age grows 2.4 percentage points per year faster than labor productivity. ${ }^{21}$

Projections for health care outlays are notoriously uncertain. For many years, analysts underpredicted the per capita spending for these rapidly expanding programs. In the past several years, however, such outlays have increased much more slowly than expected. No one is entirely sure of the reasons behind this slowdown, and it is possible that rapid growth may resume. On the other hand, growth may continue at its slower pace or slacken even more, and budgetary pressures may require limits on the expansion of medical programs.

How much do the accounts change if we look at alternative budgetary assumptions in order to allow for uncertainty or ambiguity? To find out, we examine the effects of two optimistic policies that specify lower spending for purchases and health care. ${ }^{22}$ The first holds real federal purchases constant after 2000; the second slows the growth rate of per capita Medicare outlays by age. Under the latter policy, per capita medical spending through 2003 grows at an average rate that is 2 percentage points per year slower than under the reference policy. After 2003, per capita outlays expand at the same rate as labor productivity.

\footnotetext{
20 The Act itself extended the limits on discretionary spending set by the Omnibus Budget and Reconciliation Act of 1993.

21 The Health Care Financing Administration (1997) makes similar assumptions.

22 Projected federal purchases under this assumption serve as a proxy for federal discretionary outlays. Purchases now make up about 90 percent of federal discretionary spending, which in turn accounts for around 37 percent of non-interest federal outlays.
} 
These policies depart significantly from current conditions and from the reference policy. For example, federal purchases now represent 6.0 percent of output. In 2070 , that share is 4.2 percent under the reference policy, but only 1.5 percent if real federal purchases stay constant after 2000. Total spending for Medicare is now equal to 2.7 percent of output. In 2070, it reaches 7.1 percent under the reference policy, but only 4.3 percent if that spending grows more slowly.

Given the other reference assumptions, these alternative policies reduce the generational imbalance, but do not eliminate it. If real federal purchases remain constant after 2000, the lifetime net taxes of living generations remain unchanged. However, the policy lowers projected spending for purchases. That decrease leaves a smaller residual burden on future generations, reducing their lifetime net tax rate from 49.2 to 44.6 percent (see table 7). Unlike constant purchases, slow Medicare growth boosts the per capita net taxes of every living generation (because it lowers their projected transfers). Like constant purchases, however, slow Medicare growth lessens the burden that current generations leave for future generations, and their lifetime net tax rate falls to 38.1 percent. A policy of both constant real federal purchases and slow Medicare growth yields lifetime net tax rates of 33.5 percent for future generations and 30.9 percent for current newborns. Therefore, a small generational imbalance remains despite optimistic assumptions for federal purchases and Medicare outlays.

The response of lifetime net tax rates to slower Medicare growth may seem paradoxical. Slow growth raises the lifetime net tax rate for the oldest generation the least, although that generation receives the lower transfers now. By contrast, slow growth increases that rate for the youngest generation the most, although these individuals collect the lower benefits later. This pattern occurs in part because people over age 65 will receive the smaller benefits for fewer years until death, a fact that reduces its cumulative lifetime impact.

More fundamentally, the pattern occurs because slower growth makes a greater difference over a long time horizon. For instance, if per capita benefits rise 1 percentage point per year less, benefits at age 65 will be 1 percent lower for this year's 64-year-old, 2 percent lower for this year's 63-year-old, and so forth.

Moreover, the decline in benefits at age 65 is discounted not to the base year, but to the generation's year of birth. Thus, slow Medicare growth cuts the present value of the newbom's benefit at age 65 by proportionately more than that of the one-year-old. Slower growth thus raises the lifetime net taxes (reduces the lifetime net transfers) of the current newborn by more than those of the one-year-old, boosts the net taxes of a one-year-old by more than those of a two-year-old, and so on.

\section{Alternative \\ Discount and \\ Productivity \\ Growth Rates}

The accounts also depend on uncertain assumptions about the rates of discount and productivity growth. As noted, the reference case uses a real discount rate of 6 percent $(r=0.06)$ and assumes that labor productivity eventually increases 1.2 percent per year $(g=0.012)$.

A 6 percent discount rate is roughly equal to the historical real rate of return on equity, but there are arguments for using a lower or higher rate. For example, it may be reasonable to use a discount rate closer to the real rate of return on long-term government debt ( 2 or 3 percent), or to the real pretax rate of return on private capital (10 or 12 percent). That range reflects ambiguity about how to deal with such issues as risk, opportunity cost, and the equitypremium puzzle (see CBO [1995], pp. 41-43).

In the same vein, the trend of labor productivity has varied significantly in the past, growing at an average annual rate of 1.3 percent from 1902 to 1929, 1.2 percent from 1929 to 1948, 2.8 percent from 1948 to 1966, and 0.9 percent from 1966 to $1996 .{ }^{23}$ Moreover, productivity growth swung wildly during the 1929- 48 period in response to the Depression, World War II, and demobilization. To examine the results' sensitivity to these assumptions, we next calculate generational accounts using altemative discount and productivity growth rates. The alternative assumptions are 3 percent and 9 percent for the discount rate and 0.7 percent and 1.7 percent for the productivity growth rate.

Given the reference policy, generational accounts remain imbalanced under all combinations of these growth rates, with the degree of imbalance ranging from 28 to 146 percent

23 For consistent comparison, labor productivity is defined in this example as GDP per worker. The periods seem to define growth epochs, with the first three spanning nonsuccessive peaks in the annual business cycle. There was no peak in 1966, but economists generally agree that the trend in labor productivity growth changed about then. Neither was there a peak in 1996, but it is the most recent full year for which we have data, and comes after a long (six-year) expansion. 


\section{T A B L E 8}

Percent Difference in Lifetime

Net Tax Rates of Current Newborns

and Future Generations under

Alternative Discount and Growth

Rate Assumptions ${ }^{\mathrm{a}}$

\begin{tabular}{lccc} 
& \multicolumn{3}{c}{ Growth Rate (g) } \\
\cline { 2 - 4 } Discount Rate (r) & $\mathbf{0 . 0 0 7}$ & $\mathbf{0 . 0 1 2}$ & $\mathbf{0 . 0 1 7}$ \\
\cline { 2 - 4 } $\mathbf{0 . 0 3}$ & 79 & 53 & 28 \\
$\mathbf{0 . 0 6}$ & 88 & 72 & 55 \\
$\mathbf{0 . 0 9}$ & 146 & 130 & 115 \\
\hline
\end{tabular}

a. Current newborns are the generation born in 1995. Future generations are those born in 1996 and thereafter.

SOURCE: Authors' calculations.

\section{T A B L E 9}

Percent Difference in Lifetime

Net Tax Rates of Current Newborns

and Future Generations under

Alternative Discount and Growth

Rate Assumptions, with Slower

Health Care Growth and Constant

Real Federal Purchases ${ }^{a}$

\begin{tabular}{lccc} 
& \multicolumn{3}{c}{ Growth Rate (g) } \\
\cline { 2 - 4 } Discount Rate $(\mathbf{r})$ & $\mathbf{0 . 0 0 7}$ & $\mathbf{0 . 0 1 2}$ & $\mathbf{0 . 0 1 7}$ \\
\cline { 2 - 4 } $\mathbf{0 . 0 3}$ & 1 & -4 & -10 \\
$\mathbf{0 . 0 6}$ & 6 & 8 & 11 \\
$\mathbf{0 . 0 9}$ & 40 & 45 & 51 \\
\hline
\end{tabular}

a. Current newborns are the generation bom in 1995. Future generations are those borm in 1996 and thereafter.

SOURCE: Authors' calculations.

\section{F I G U R E 2}

\section{U.S. Population and Projections ${ }^{a}$}

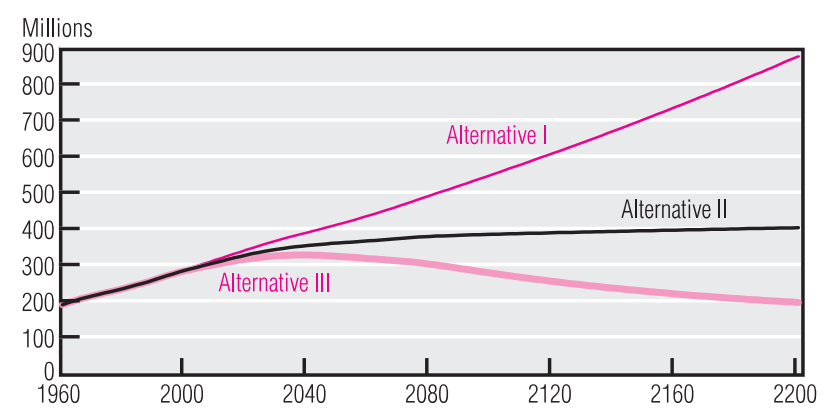

a. Actual data through 1995.

SOURCES: Social Security Administration; and authors' calculations. (see table 8). Given the alternative spending policies, some combinations of discount and productivity growth rates tip the generational scales in favor of the future. Most do not, however, and the degree of imbalance ranges from -10 to 51 percent (see table 9). Lifetime net tax rates on future generations fall below those on current newborns only at a low discount rate and a moderate or high growth rate.

The degree of imbalance responds more to the differences considered for the discount rate than the productivity growth rate. A higher discount rate typically makes the residual burden accumulate faster and thereby raises the degree of imbalance. ${ }^{24}$ On the other hand, higher productivity growth tends to boost income and output, and they in turn feed into higher values for purchases and the net taxes of living generations (see CBO [1997b]). That phased-in response dilutes the impact of higher productivity growth on the lifetime net tax rates of all generations. ${ }^{25}$

\section{Alternative \\ Demographic \\ Projections}

Uncertainty about population growth also afflicts generational accounts (or any other longrun projection). As noted, the accounts use the SSA's intermediate projection for a base case

24 This statement is true as long as the sum of the current value of government net debt, $N W G_{t}$, plus the present value of prospective government purchases, $P V G$, exceeds the present value of prospective net taxes of living generations, $P V L_{t}$. The condition is easily satisfied for any reasonable values.

25 Seemingly paradoxical reversals sometimes occur. For example, suppose that the discount and productivity growth rates shown in table 8 move from 3 to 6 percent and from 0.7 to 1.2 percent, respectively. The degree of imbalance then falls from 79 to 72 percent. However, it subsequently rises to 115 percent as the discount and productivity growth rates move higher to 9 percent and 1.7 percent. Such reversals occur both because the degree of imbalance is a ratio and because the discounting process can lead to the same kind of "reswitching" issues that arise in capital theory. A higher discount rate reduces the absolute present value in any year a tax is paid or a wage transfer is received. A higher productivity growth rate raises those absolute present values. Therefore, a lifetime net tax rate may go up or down if both the discount and productivity growth rates are higher. Moreover, people generally pay taxes in youth and middle age and receive transfers in old age. Other things equal, a higher discount rate reduces the present value of both taxes and transfers, so that the present value of net taxes (taxes less transfers) may rise or fall. A higher discount rate is more likely to raise the present value of net taxes in the following cases: the initial discount or productivity growth rate is higher, the recipient receives a given transfer at a later age, or the recipient gets a larger transfer at a given age (as in the earlier case of slow Medicare growth, when the newborn's benefit at age 65 is cut by proportionately more than that of the one-year-old). 


\section{F I G U R E 3}

Old-Age Dependency Ratio

under Alternative Population

Projections $^{\mathrm{a}}$

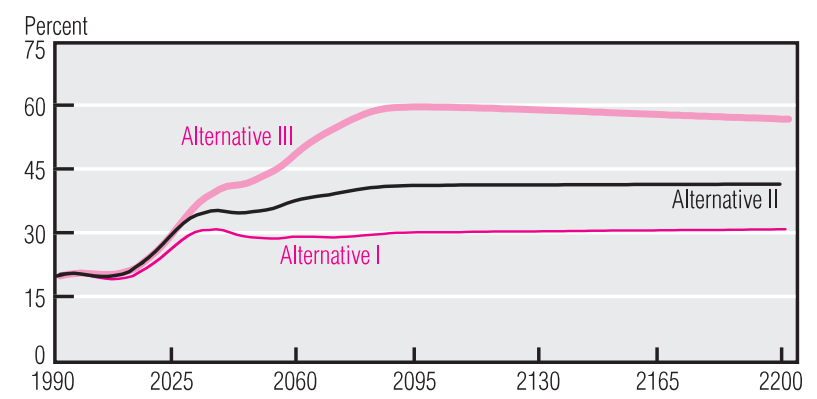

a. Population aged 65 or older as a share of population aged 20 to 64 . SOURCES: Social Security Administration; and authors' calculations.

\section{T A B L E 10}

Generational Accounts

under Alternative

Demographic Assumptions ${ }^{a}$

\begin{tabular}{|c|c|c|c|c|c|c|}
\hline \multirow{3}{*}{$\begin{array}{l}\text { Generation's } \\
\text { Age in } \\
1995 \\
\end{array}$} & \multicolumn{6}{|c|}{ Net Tax Payments under Alternatives } \\
\hline & \multicolumn{2}{|c|}{ I } & \multicolumn{2}{|r|}{ III } & \multicolumn{2}{|c|}{ III } \\
\hline & Male & Female & Male & Female & Male & Female \\
\hline 0 & 75.4 & 50.3 & 77.4 & 51.9 & 79.8 & 53.6 \\
\hline 5 & 94.1 & 62.1 & 95.7 & 63.4 & 97.7 & 65.0 \\
\hline 10 & 118.8 & 77.1 & 119.5 & 78.1 & 121.0 & 79.4 \\
\hline 15 & 149.3 & 95.1 & 149.1 & 95.7 & 149.8 & 96.7 \\
\hline 20 & 183.3 & 114.8 & 182.2 & 115.0 & 181.9 & 115.6 \\
\hline 25 & 195.8 & 121.7 & 196.2 & 122.6 & 196.5 & 123.6 \\
\hline 30 & 195.7 & 119.4 & 196.8 & 120.7 & 197.2 & 121.8 \\
\hline 35 & 187.7 & 112.5 & 189.0 & 113.8 & 189.2 & 114.8 \\
\hline 40 & 170.0 & 98.1 & 171.2 & 99.0 & 171.7 & 99.7 \\
\hline 45 & 138.3 & 72.2 & 139.2 & 72.8 & 139.8 & 73.2 \\
\hline 50 & 93.3 & 37.3 & 93.7 & 37.4 & 94.0 & 37.4 \\
\hline 55 & 37.6 & -4.8 & 37.5 & -5.2 & 37.3 & -5.7 \\
\hline 60 & -24.8 & -51.0 & -25.5 & -52.0 & -26.3 & -53.0 \\
\hline 65 & -76.3 & -89.4 & -77.7 & -91.2 & -79.0 & -92.8 \\
\hline 70 & -87.5 & -98.8 & -89.2 & -101.0 & -90.9 & -103.1 \\
\hline 75 & -86.1 & -98.6 & -87.9 & -101.0 & -89.7 & -103.2 \\
\hline 80 & -75.6 & -88.1 & -77.2 & -90.2 & -78.9 & -92.2 \\
\hline 85 & -66.9 & -72.0 & -68.3 & -73.5 & -69.6 & -75.1 \\
\hline 90 & -52.8 & -54.8 & -53.8 & -55.8 & -54.8 & -56.8 \\
\hline & 116.6 & 77.8 & 134.6 & 90.2 & 153.7 & 103.3 \\
\hline \multirow{3}{*}{$\begin{array}{l}\text { Percent } \\
\text { difference }\end{array}$} & & & & & & \\
\hline & L2. & U..1 & 11.0 & 10. & & 4 \\
\hline & \multicolumn{6}{|c|}{ Lifetime Net Tax Rates (percent) } \\
\hline
\end{tabular}

\begin{tabular}{llll}
\hline Current & & & \\
newborns & 26.8 & 28.6 & 30.3 \\
FG $^{\mathrm{b}}$ & 40.9 & 49.2 & 57.6 \\
\hline
\end{tabular}

a. Present value in thousands of 1995 dollars.

b. Future generations.

c. Lifetime net tax rates are population-weighted averages across males and females.

SOURCE: Authors' calculations. (and extend it as described earlier). However, the SSA also projects high- and low-growth paths to try to describe a reasonable range of uncertainty about its estimates for the probable actuarial balance of the Social Security trust fund. The three population projections represent low-cost (Alternative I), mid-cost (Alternative II), and high-cost (Alternative III) outcomes.

The differences in populations depend on differences in their fertility, mortality, and net immigration rates. Alternative I assumes the highest rates for all of those demographic factors, and Alternative III assumes the lowest. Higher rates imply more workers paying taxes and fewer retirees receiving transfers; lower rates imply the opposite. Compared to Altemative II, the population of Alternative I about doubles, while the population of Alternative III falls to about half the size (see figure 2). ${ }^{26}$

All of the alternatives show a rise in the oldage dependency ratio - the population aged 65 or older as a share of the population aged 20 to 64 . As the baby boom generations retire, that ratio increases during the years from about 2010 to 2035 (see figure 3). The ratio for Alternative II then levels off, with fertility and immigration rates largely offsetting its mortality rates to roughly stabilize the size and age composition of the population. The ratio for Altemative I falls, since higher mortality rates reduce the relative number of old people, and higher fertility and immigration rates expand the relative number of working-age people. The opposite occurs under Alternative III.

For living generations, higher mortality and immigration rates usually imply higher generational accounts for the old and lower ones for the young (see table 10). For instance, the accounts of old generations are higher (less negative) under Alternative I than under Alternative II, while the accounts of very young generations are lower. The higher mortality rates associated with Alternative I imply that fewer people of any age live to any given year in the future. People now old will receive less in transfers, and people now young will pay less in taxes (whose present value is greater than that of the later transfers they would otherwise receive).

The pattern is not strictly consistent, because net immigration boosts the later size of some young generations. For instance, the generational account for 20-year-old males is highest

26 Another way to compare these alternatives is to look at their populations in 2200 as ratios of the population in 1995. Under Alternative I, the population increases by the year 2200 to more than 300 percent of its 1995 level; under Alternative II, it rises to about 150 percent of its 1995 level; and under Alternative III, it declines to about 70 percent of its 1995 level. 
under Alternative I. That apparent anomaly reflects the prospective U.S. net taxes of the current foreign 20-year-old males who will immigrate later. That is, the population count in the base year excludes their present numbers, but the generational account includes their prospective taxes and transfers. In effect, the accounts assign those prospective net taxes to the current population of 20-year-old U.S. males. That assignment raises the (per capita) generational account; a higher immigration rate increases it still more.

The accounts of living generations typically vary by less than 2 percent in response to population differences. The percentage differences tend to be greatest at the ages with the highest mortality rates - newborns and seniors. The alternative populations assume greater differences in their mortality rates and thus imply greater proportional differences in their generational accounts. Fertility rates affect only the population of future generations, not the accounts of current generations.

For future generations, fertility, mortality, and net immigration rates all play a role. The higher fertility rates of Alternative I imply larger future generations to share the residual burden, thereby reducing their lifetime net tax rates. Higher mortality rates play a smaller and partly offsetting role. Fewer young people live to pay taxes in middle age, fewer middle-aged people live to collect benefits in old age, and fewer old people live to collect them for as long a period. Given the age pattern of net immigration, a higher immigration rate implies relatively more workers.

The lifetime net tax rates of future generations respond more to altemative populations than do those of current newborns. Even if differences in mortality produce a relatively small change in the account of any one current generation, their combined effect produces a relatively large change in the residual burden on future generations. Under the various population assumptions, the lifetime net tax rate for future generations ranges from about 41 percent under Alternative I to about 58 percent under Alternative III. The degree of generational imbalance ranges from 52 percent under Alternative I to 90 percent under Alternative III. Thus, even under optimistic assumptions about the population, the reference policy remains unsustainable.

\section{Policies for \\ Eliminating \\ Generational \\ Imbalance}

\section{Alternative Ways \\ to Indicate the Extent \\ of Generational \\ Imbalance}

So far, we have assumed that living generations pay net taxes as scheduled for the rest of their lives. The spending side of the fiscal schedules examined here have followed the reference policy or an alternative policy (either constant real federal purchases or slow growth in Medicare outlays, or both). We have further assumed that all future generations share the resulting residual burden proportionately by paying the same lifetime net tax rate. Given the other reference assumptions, each policy we have considered has been generationally imbalanced (that is, future generations must pay a higher lifetime net tax rate than current newborns) and is thus unsustainable.

Some observers have criticized this way of analyzing the generational stance of fiscal policy, arguing that if a fiscal schedule is unsustainable, lawmakers will change it so that some or all living generations will pay higher net taxes, and future generations will pay less than they otherwise would have (see, for example, Eisner [1994] and Haveman [1994]). ${ }^{27}$ To address this concern, we now calculate policy changes that would equalize the lifetime net tax rates of current newborns and future generations. The policies we examine involve permanently raising particular taxes or cutting particular outlays by a policy-specific percentage starting in 1998, 2003, or 2016. The different policies result in different equalized lifetime net tax rates on current newborn and future generations, and require different dollar amounts of tax increases or outlay cuts in the first year of their implementation.
- 27 Another criticism stems from the Ricardian equivalence proposition, which states that current generations, perceiving that higher current deficits entail higher net taxes on future generations, will respond by increasing their saving and bequests. However, formal tests fail to detect the altruistic behavior required for Ricardian equival ence to hold. See Altonji, Hayashi, and Kotlikoff (1992, 1997). 


\section{T A B L E 11}

Policies for Equalizing the

Lifetime Net Tax Rates of Current

Newborns and Future Generations ${ }^{\mathrm{a}}$

Required Percentage Change

Equalized Lifetime Net Tax Rate

\begin{tabular}{|c|c|c|c|c|c|c|c|c|}
\hline & \multicolumn{4}{|c|}{ Required Percentage Change } & \multicolumn{4}{|c|}{ Equalized Lifetime Net Tax Rate } \\
\hline & $\begin{array}{l}\text { Ref. } \\
\text { (1) }\end{array}$ & $\begin{array}{l}\text { Slower } \\
\text { Purchases } \\
\text { Growth } \\
\text { (2) }\end{array}$ & $\begin{array}{c}\text { Slower } \\
\text { Health } \\
\text { Care } \\
\text { Growth } \\
\text { (3) }\end{array}$ & $\begin{array}{l}\text { Slower } \\
\text { Health Care } \\
\text { and } \\
\text { Purchases } \\
\text { Growth } \\
\text { (4) }\end{array}$ & $\begin{array}{l}\text { Ref. } \\
\text { (5) }\end{array}$ & $\begin{array}{l}\text { Slower } \\
\text { Purchases } \\
\text { Growth }^{\text {b }} \\
\text { (6) }\end{array}$ & $\begin{array}{l}\text { Slower } \\
\text { Health } \\
\text { Care } \\
\text { Growth } \\
\text { (7) }\end{array}$ & $\begin{array}{l}\text { Slower } \\
\text { Health } \\
\text { Care and } \\
\text { Purchases } \\
\text { Growth } \\
\text { (8) }\end{array}$ \\
\hline \multicolumn{9}{|c|}{ No change in lifetime net tax rates } \\
\hline Current newborns & - & - & - & - & 28.6 & 28.6 & 30.9 & 30.9 \\
\hline \multirow[t]{2}{*}{ Future generations } & - & - & - & - & 49.2 & 44.6 & 38.1 & 33.5 \\
\hline & \multicolumn{8}{|c|}{ Panel A: Policy Change in 1998} \\
\hline $\begin{array}{l}\text { Tax increases } \\
\text { Income tax } \\
\text { Income tax (federal only) } \\
\text { Payroll tax } \\
\text { Other taxes } \\
\text { All taxes }\end{array}$ & $\begin{array}{l}20.4 \\
24.9 \\
31.0 \\
39.7 \\
8.9\end{array}$ & $\begin{array}{c}15.8 \\
19.4 \\
24.1 \\
30.8 \\
6.9\end{array}$ & $\begin{array}{c}7.1 \\
8.7 \\
10.8 \\
13.8 \\
3.1\end{array}$ & $\begin{array}{l}2.6 \\
3.1 \\
3.9 \\
5.0 \\
1.1\end{array}$ & $\begin{array}{l}31.9 \\
31.9 \\
32.4 \\
33.3 \\
32.3\end{array}$ & $\begin{array}{l}31.1 \\
31.1 \\
31.6 \\
32.2 \\
31.5\end{array}$ & $\begin{array}{l}32.1 \\
32.1 \\
32.3 \\
32.6 \\
32.2\end{array}$ & $\begin{array}{l}31.3 \\
31.3 \\
31.4 \\
31.5 \\
31.4\end{array}$ \\
\hline \multicolumn{9}{|l|}{ Transfer cuts } \\
\hline Social Security $f$ & 47.5 & 36.9 & 16.5 & 5.9 & 30.1 & 29.8 & 31.4 & 31.1 \\
\hline Health care & 36.8 & 28.6 & 16.8 & 6.0 & 31.3 & 30.7 & 31.8 & 31.2 \\
\hline All transfers & 18.5 & 14.3 & 7.3 & 2.6 & 31.0 & 30.5 & 31.7 & 31.2 \\
\hline \multicolumn{9}{|l|}{ Purchases cuts } \\
\hline \multirow{3}{*}{$\begin{array}{l}\text { Entire government } \\
\text { Federal }\end{array}$} & 15.4 & 12.3 & 5.3 & 2.0 & 28.6 & 28.6 & 30.9 & 30.9 \\
\hline & 38.7 & 31.1 & 13.5 & 5.0 & 28.6 & 28.6 & 30.9 & 30.9 \\
\hline & \multicolumn{8}{|c|}{ Panel B: Policy Change in 2003} \\
\hline $\begin{array}{l}\text { Tax increases } \\
\text { Income tax }^{d}\end{array}$ & 25.3 & 19.7 & 8.8 & 3.2 & 32.6 & 31.7 & 32.3 & 31.4 \\
\hline Income tax (federal only) & 31.0 & 24.1 & 10.8 & 3.9 & 32.6 & 31.7 & 32.3 & 31.4 \\
\hline Payroll tax & 38.7 & 30.1 & 13.5 & 4.8 & 33.4 & 32.3 & 32.6 & 31.5 \\
\hline Other taxes ${ }^{\mathrm{e}}$ & 50.8 & 39.5 & 17.7 & 6.4 & 34.0 & 32.8 & 32.8 & 31.6 \\
\hline All taxes & 11.2 & 8.7 & 3.9 & 1.4 & 33.1 & 32.1 & 32.5 & 31.5 \\
\hline \multicolumn{9}{|l|}{ Transfer cuts } \\
\hline Social Security $\mathrm{f}$ & 57.4 & 44.6 & 20.0 & 7.2 & 30.3 & 29.9 & 31.5 & 31.1 \\
\hline Health care & 42.2 & 32.8 & 20.2 & 7.3 & 31.6 & 31.0 & 31.9 & 31.3 \\
\hline All transfers & 21.8 & 16.9 & 8.8 & 3.2 & 31.3 & 30.7 & 31.8 & 31.3 \\
\hline \multicolumn{9}{|l|}{ Purchases cuts } \\
\hline \multirow{3}{*}{$\begin{array}{l}\text { Entire government } \\
\text { Federal }\end{array}$} & 19.5 & 15.8 & 6.8 & 2.5 & 28.6 & 28.6 & 30.9 & 30.9 \\
\hline & 50.1 & 40.6 & 17.4 & 6.5 & 28.6 & 28.6 & 30.9 & 30.9 \\
\hline & \multicolumn{8}{|c|}{ Panel C: Policy Change in 2016} \\
\hline $\begin{array}{l}\text { Tax increases } \\
\text { Income tax }\end{array}$ & & & & & & & & \\
\hline $\begin{array}{l}\text { Income tax } \mathrm{d} \\
\text { Income tax (federal onlv) }\end{array}$ & 45.4 & 35.2 & 15.8 & 5.7 & 35.5 & 34.0 & $\begin{array}{r}33.3 \\
232\end{array}$ & $\begin{array}{l}31.8 \\
31.8\end{array}$ \\
\hline $\begin{array}{l}\text { Income tax (federal only) } \\
\text { Payroll tax }\end{array}$ & $\begin{array}{l}55.3 \\
70.3\end{array}$ & $\begin{array}{l}43.0 \\
54.6\end{array}$ & $\begin{array}{l}19.2 \\
24.5\end{array}$ & $\begin{array}{l}6.9 \\
8.8\end{array}$ & $\begin{array}{l}35.6 \\
36.9\end{array}$ & $\begin{array}{l}34.0 \\
35.0\end{array}$ & $\begin{array}{l}33.3 \\
33.8\end{array}$ & $\begin{array}{l}31.8 \\
32.0\end{array}$ \\
\hline Other taxese & 102.0 & 79.2 & 35.5 & 12.8 & 35.9 & 34.3 & 33.5 & 31.9 \\
\hline All taxes & 20.6 & 16.0 & 7.2 & 2.6 & 35.9 & 34.3 & 33.5 & 31.8 \\
\hline \multicolumn{9}{|l|}{ Transfer cuts } \\
\hline Social Security $f$ & 94.9 & 73.8 & 33.0 & 11.9 & 30.8 & 30.3 & 31.7 & 31.2 \\
\hline Health care & 63.7 & 49.5 & 32.7 & 11.7 & 32.7 & 31.8 & 32.3 & 31.4 \\
\hline All transfers & 34.6 & 26.9 & 14.6 & 5.2 & 32.4 & 31.5 & 32.2 & 31.4 \\
\hline \multicolumn{9}{|l|}{ Purchases cuts } \\
\hline Entire government & 35.4 & 30.0 & 12.3 & 4.8 & 28.6 & 28.6 & 30.9 & 30.9 \\
\hline Federal & 92.5 & 78.4 & 32.2 & 12.6 & 28.6 & 28.6 & 30.9 & 30.9 \\
\hline
\end{tabular}

a. Current newborns are the generation born in 1995. Future generations are those born in 1996 and thereafter. Figures are percentages.

b. Federal purchases are held constant in real terms after the year 2000.

c. Per capita spending by age on health care grows 2 percentage points slower than under the reference policy through 2003 , then increases at the same rate as labor productivity.

d. Federal, state, and local.

e. Includes excise taxes, other indirect taxes, and property taxes.

f. Federal Old-Age and Survivors Insurance and Disability Insurance Trust Funds.

NOTE: Calculations incorporate CBO projections.

SOURCE: Authors' calculations. 


\section{Percentage \\ Changes Needed \\ in Various Programs \\ to Reach Balance}

The first two rows of table 11 repeat the lifetime net tax rates on current newborns and future generations under the alternative assumptions. The remaining rows list altemative tax, transfer, or purchase policies that may be used to restore generational balance, while the columns indicate the assumptions (reference, constant real purchases, slow health care growth, and so on) underlying the calculations. The first four columns show the required percentage change, and the last four columns indicate the equalized value of the lifetime net tax rate under each row-specific policy and column-specific assumption. ${ }^{28}$

Given the other reference assumptions, balance can be achieved in 1998 by permanently raising the schedules for all income taxes on current generations by 20.4 percent (panel A, row 1, column 1). That equalizes lifetime tax rates at 31.9 percent, raising the rate on current newborns from 28.6 percent and lowering the rate on future newborns from 49.2 percent (panel A, row 1, column 5). If real federal purchases remain constant after 2000, the required hike in income taxes is 15.8 percent, implying an equalized lifetime net tax rate of 31.1 percent (panel A, row 1, columns 2 and 6). If Medicare spending grows slowly, the income tax hike is even smaller (7.1 percent), but the equalized lifetime net tax rate rises (32.1 percent). With constant real federal purchases and a deceleration in Medicare outlays, the required tax increase is smaller yet (2.6 percent), and the equalized lifetime net tax rate is 31.3 percent.

Similarly, if we fix the other reference assumptions and change the various fiscal programs, balance can be reached via several alternative policies, including a hike in taxes of 8.9 percent, a cut in Social Security transfers of 47.5 percent, a cut in health care outlays of 36.8 percent, or a reduction in all purchases of 15.4 percent (column 1). These policies equalize the lifetime net tax rates of current newborns and future generations at values that differ by policy, namely, 32.3 percent for raising all taxes, 30.1 percent for cutting Social Security benefits, 31.3 percent for cutting all health care benefits, and 28.6 percent for cutting all purchases. (The reasons for these differences are explained below.)

\section{Variation in \\ Percentage Changes \\ and Equalized \\ Lifetime Net \\ Tax Rates}

Why do the percentage changes and the equalized lifetime net tax rates differ across each row and down each column of table 11? Moving across each row, the respective percentage changes are lower because the underlying assumptions involve progressively smaller degrees of initial imbalance. Hence, restoring balance requires progressively smaller percentage changes in a row-specific policy.

Across each row, there is no general pattern for the level of the equalized lifetime net tax rate, but there is a pattern for the change in the lifetime net tax rate of current newborns. For a change in a given tax or transfer, the change in that lifetime rate is smaller as we move across each row. For example, an increase in the income tax that restores balance raises the lifetime net tax rate of current newborns by 3.3 percentage points under the reference policy (31.9 percent versus 28.6 percent). But that lifetime rate rises by 2.5 percentage points when real purchases remain constant, by 1.2 percentage points when Medicare spending grows slowly, and by 0.4 percentage point when real purchases remain constant and Medicare spending grows slowly.

For a cut in purchases, the net taxes of all living generations remain unchanged, so the lifetime net tax rate of current newborns stays at its initial value as we move across each row. However, cutting purchases lowers the residual burden on future generations, and achieving balance requires that the cut be large enough to reduce the rate on future generations until it equals that on current newborns.

For a column-specific initial policy, variation in the outcome depends largely on which generations are most affected by the row-specific change in policy. On average, older individuals pay more in taxes on capital income and receive more in transfers from Social Security, Medicare, and Medicaid. Thus, a change in the schedule for such a tax or transfer will make every living generation contribute more - the old now, the young later. By contrast, a change

28 A table indicating the initial dollar amounts of revenue increases and transfer or purchase reductions for each of the policies considered in table 11 is available from the authors upon request. 
in the schedule for a program that primarily affects young individuals effectively reduces the number of generations that make additional contributions. Therefore, between two programs of the same initial size, an equalizing policy that affects the old more than the young will require both a smaller percentage change and a smaller increase in the lifetime net tax rate on current newborns. The aging of the population and the rapid rise in medical costs greatly magnify these effects.

\section{Costs of Waiting}

Waiting for five years, until 2003, before undertaking such policies requires larger changes than acting sooner (compare the first four columns in panel B with those in panel A). Under the reference scenario, the delay in trimming purchases again leaves the equalized lifetime net tax rate at the same level as that for current newborns. However, the required percentage cut is larger than when action is taken sooner (19.5 versus 15.4 percent). Acting later to raise taxes or to cut transfers results in a higher equalized lifetime net tax rate than does acting sooner. The delay implies that some living generations escape the higher taxes or lower transfers, meaning that living and future generations must each bear higher lifetime net tax rates.

Waiting until the year 2016- about the time the largest baby boom generations will retirerequires even greater changes (see panel C). Again, except for purchase cuts, the lifetime net tax rates in panel $\mathrm{C}$ are higher than their counterparts in panel B. Such a long delay in restoring balance will involve unrealistically high tax increases, benefit cuts, or purchase reductions. For example, it would mean defaulting on 95 percent of Social Security's implicit obligations to living generations.

\section{Conclusion}

Reasonable economic and demographic assumptions imply that the generational stance of U.S. fiscal policy remains seriously imbalanced. Although the degree of this imbalance has declined from two years ago, the reference scenario implies lifetime net tax rates of 49.2 percent for future generations and 28.6 percent for current newborns. The schedule of such a policy cannot persist. At some point, projected government purchases must fall or scheduled net tax rates must rise - if not for living generations, then for future ones. We have described the sizes of hypothetical policy changes that would restore generational balance. They appear large, but failure to act soon will require even bigger changes in the future.

\section{Appendix 29}

\section{The Method of Generational Accounting}

The method of generational accounting takes as its starting point the govemment's present-value (intertemporal) budget constraint. This constraint is the same as equation (1) in the text and is reproduced here only for convenience.

$$
\mathrm{PVG}_{\mathrm{t}}=\mathrm{NWG}_{\mathrm{t}}+\mathrm{PVL}_{\mathrm{t}}+\mathrm{PVF}_{\mathrm{t}}
$$

Equation (A1) says that at time $t$ (the base year), the present value of prospective government purchases of goods and services, $\mathrm{PVG}_{t}$, must be paid for by the sum of three items: the net wealth of the government, $\mathrm{NWG}_{\mathrm{t}}$; the present value of prospective aggregate net tax payments by generations living at time $t, \mathrm{PVL}_{\mathrm{t}}$; and the present value of aggregate net tax payments by future generations born after time $t, \mathrm{PVF}_{\mathrm{t}}$. The term "net tax payments" refers to taxes paid to the govemment net of transfers received from it. The "generational account" is a dollar amount, defined as the actuarially discounted present value of per capita net tax payments of a generation over the rest of its life.

Note that equation (A1) can be viewed as a financing constraint. Under a given policy for prospective government purchases, future generations must pay for the purchases that are not covered by the government's current net wealth plus living generations' prospective net taxes. Generational accounting examines how alternative fiscal policies would affect the size of the aggregate required net payment, its division between $\mathrm{PVL}_{t}$ and $\mathrm{PVF}_{t}$, and, under certain assumptions, its distribution across living and future generations. The following discussion describes the method for estimating the components of equation (A1). 
The sum of generational accounts over all members of living generations, $\mathrm{PVL}_{t}$, can be written as

$$
\mathrm{PVL}_{\mathrm{t}}=\sum_{j_{\mathrm{t}}=0}^{\mathrm{D}}\left(\mathrm{n}_{\mathrm{j}_{\mathrm{t}}, \mathrm{t}}^{\mathrm{m}} \mathrm{p}_{\mathrm{j}_{\mathrm{t}}, \mathrm{t}}^{\mathrm{m}}+\mathrm{n}_{\mathrm{j}_{\mathrm{t}}, \mathrm{t}}^{\mathrm{f}} \mathrm{p}_{\mathrm{j}_{\mathrm{t}}, \mathrm{f}}^{\mathrm{f}}\right)
$$

where D is the maximum age of life, $\mathrm{p}_{\mathrm{j}_{\mathrm{t}}, \mathrm{t}}^{\mathrm{t}}$ and $\mathrm{p}_{\mathrm{j}_{\mathrm{t}}, \mathrm{t}}^{\mathrm{f}}$ represent the populations of males and females, and $\mathrm{n}_{\mathrm{j}_{\mathrm{t}}, \mathrm{t}}^{\mathrm{m}}$ and $\mathrm{n}_{\mathrm{j}_{\mathrm{t}}, \mathrm{t}}^{\mathrm{f}}$ represent the generational accounts in year $t$ of males and females aged $j$ in year $t$ (indexed by $j_{t}$ ) - that is, the respective present values as of year $t$ of the per capita net taxes they will pay over the rest of their lives.

The generational account, $n{ }_{j}^{x}, t$, where the superscript $x$ stands for male or female, is defined by

$$
\mathrm{n}_{\mathrm{j}_{\mathrm{t}}, \mathrm{t}}^{\mathrm{x}}=\frac{1}{\mathrm{p}_{\mathrm{j}_{\mathrm{t}}, \mathrm{t}}^{\mathrm{x}}} \sum_{s=\mathrm{t}}^{\mathrm{t}+\mathrm{D}-\mathrm{j}_{\mathrm{t}}} \mathrm{p}_{\mathrm{j}_{\mathrm{t}}, \mathrm{s}}^{\mathrm{x}}\left(\sum_{\mathrm{i}=1}^{\mathrm{m}} \mathrm{q}_{\mathrm{i}, \mathrm{j}_{\mathrm{t}}, \mathrm{s}}^{\mathrm{x}}\right) \mathrm{R}^{\mathrm{s}-\mathrm{t}}
$$

where $R=1 /(1+r)$, and $r$ is the discount rate. Equation (A3) expresses the actuarially discounted value of prospective per capita net payments of a generation aged $j$ at time t. The account for each generation is calculated by 1) finding the algebraic sum of the per capita taxes and transfers paid in each year s by the members surviving in that year (including people of that age and sex who have immigrated since year t), 2) multiplying that sum by the population in year $\mathrm{s}, 3$ ) discounting the result back to time $t, 4)$ aggregating such discounted values over the generation's lifetime, and 5) dividing the result by the generation's population in yeart. In equation (A3), $q_{i, j}^{x}, s$ stands for the per capita payment (or receipt, when $q$ is negative) of type i in year s (>t) by a generation of sex $x$ aged $j$ in year $t$. The per capita net payment-after accounting for all $(\mathrm{m})$ types of taxes and transfers in year s- is given by the sum in parentheses. This term, multiplied by the population of such persons in year $\mathrm{s}, \mathrm{p}_{\mathrm{j}_{\mathrm{t}}, \mathrm{s}}^{\mathrm{x}}$, yields the aggregate net payment that individuals of sex $\mathrm{x}$ aged $\mathrm{j}$ in year $t$ make in year $\mathrm{s}^{30}$ Summing such discounted values for each year $s$ over the remaining life of individuals aged $\mathrm{j}$ in year $\mathrm{t}$ (from $t$ to $t+D-j_{t}$ ) yields the discounted value of their aggregate net payments. Division by $\mathrm{p}_{\mathrm{j}_{\mathrm{t}}, \mathrm{t}}^{\mathrm{x}}$, the population of such persons in year $\mathrm{t}$, converts this actuarially discounted sum to a per capita amount and represents the generational account of the generation aged $j$ in year t.
The prospective per capita payments of each type of tax (or transfer) are estimated by distributing projected aggregate payments of that type by age and sex. In making the distribution, generational accounting begins with projections of population and of aggregate taxes and transfers. To each type of aggregate tax or transfer projection, it applies a relative profile by age and sex normalized to a 40-year-old male. For example, the relative profile value for a 38year-old woman is the ratio of her payment to that of a 40-year-old man. Relative profiles for various taxes and transfers are estimated from survey data, and the latest available profiles are used to distribute projected aggregate payments by age and sex in future years. ${ }^{31}$ Projections of aggregate payments may be unavailable for years far into the future. In this case, the relative profiles are used to distribute, by age and sex, the aggregate payments in the last available year (actual or projected). This yields per capita payments by age and sex for that year. Per capita values for later years are obtained by making the per capita values for the last available year grow at the same rate as labor productivity $(g)$. Hence, if the last available year is $\mathrm{s}$,

$$
q_{i, j t, s+k}^{x}=q_{i, j_{t}, s}^{x}(1+g)^{k}, i=1,2, \ldots m .
$$

The relative profiles and associated aggregate payments and receipts specify the pattern of prospective per capita payments and receipts imposed on various generations living at time $t$, and therefore collectively embody the generational stance of fiscal policy at time $t$. Because all relative profiles are normalized to average payments by 40 -year-old males, the per capita payment by 40 -year-old males can be expressed as

$$
\mathrm{q}_{\mathrm{i}, 40_{\mathrm{t}}, \mathrm{t}}^{\mathrm{x}}=\frac{\mathrm{Q}_{\mathrm{i}, \mathrm{t}}}{\sum_{\mathrm{j}_{\mathrm{t}}=0}^{\mathrm{D}}\left(\mathrm{r}_{1, j_{\mathrm{t}}, \mathrm{t}}^{\mathrm{m}} \mathrm{p}_{\mathrm{Jt}, \mathrm{t}}^{\mathrm{m}}+\mathrm{r}_{\mathrm{i}, \mathrm{j}_{\mathrm{t}}, \mathrm{t}}^{\mathrm{f}} \mathrm{p}_{\mathrm{ft}_{\mathrm{t}} \mathrm{f}}^{\mathrm{f}}\right)} .
$$

30 For the United States, estimates of $p_{j_{t}}^{X}$, sare those of the SSA.

31 For the United States, these estimates are taken from the University of Michigan's Survey of Income and Program Participation, the Census Bureau's Current Population Survey, the SSA's Annual Statistical Supplement to the Social Security Bulletin, the Health Care Financing Administration, and the Survey of Current Business. For a discussion of the treatment of individual taxes and transfers, see Auerbach, Gokhale, and Kotlikoff $(1991,1994)$ and Kotlikoff (1992). 
Here, $r_{1, j}^{x}, t$ represents the per capita payment (or receipt, if negative) of type i that a person aged $\mathrm{j}$ in year $\mathrm{t}$ makes relative to the payment of a 40-year-old male in year $t$, and $\mathrm{Q}_{\mathrm{i}, \mathrm{t}}$ represents the aggregate payment of type i made in year t. Of course,

$$
\begin{aligned}
& q_{1, j}^{x}, t=q_{1,40 t}^{x}, r_{1, j}^{x}, t \\
& x=m, f ; j_{t}=0 \ldots D .
\end{aligned}
$$

$\mathrm{PVG}_{\mathrm{t}}$ is estimated by discounting prospective aggregate govemment purchases back to year t. If projections of aggregate purchases are unavailable or need to be extended, they are estimated by distributing, according to age, the per capita purchases in the last year (actual or projected) for which an aggregate figure is available, by making the per capita purchases by age grow at the same rate as labor productivity, and finally, by using a population projection to aggregate the per capita figures. ${ }^{32}$ As with the per capita distribution of taxes and transfers, the estimates for purchases assume a constant relative profile by age - a set of empirically determined ratios that represent an element of the current generational stance of fiscal policy.

Government net wealth, $\mathrm{NWG}_{\mathrm{t}}$, can be estimated by cumulating the sum of past government surpluses (or deficits, if negative). The government's existing tangible assets, such as parks and infrastructure, are excluded from $\mathrm{NWG}_{\mathrm{t}}$, and their prospective service flows, which represent the consumption of public goods, are excluded from $\mathrm{PVG}_{\mathrm{t}}$. If these assets were included in $\mathrm{NWG}_{\mathrm{t}}$, their service flows would have to be included in $\mathrm{PVG}_{\mathrm{t}}$. Because the value of the assets must, by definition, equal the present value of their consumption flows, they would cancel each other if they were included in equation (A1). Thus, the exclusions do not affect the trade-off between $\mathrm{PVL}_{\mathrm{t}}$ and $\mathrm{PVF}_{\mathrm{t}}$.

Because equation (A1) must hold at time t, and because three of the four elements in that equation have been estimated, the fourth term, $\mathrm{PVF}_{\mathrm{t}}$, can be calculated as a residual. The distribution of this residual aggregate net payment among unborn generations is indeterminate. As an illustrative device, therefore, generational accounting distributes the residual burden, $\mathrm{PVF}_{\mathrm{t}}$, among all future generations on an equal (growth-adjusted) basis. That is, if labor productivity grows at rate $g$, the generational account of each future generation is $(1+g)$ times that of its immediate predecessor. The ratio of the generational account of future males to that of future females born in the same year is kept equal to the corresponding ratio under the assumed policy for current newborn males and females (who are members of living generations). Hence,

$$
\begin{aligned}
& \mathrm{PVG}_{\mathrm{t}}-\mathrm{NWG}_{\mathrm{t}}-\mathrm{PVL}_{\mathrm{t}}= \\
& \sum_{\mathrm{s}=\mathrm{t}+1}^{\infty}\left(\mathrm{n}_{0_{\mathrm{s}^{\prime}}}^{\mathrm{m}} \mathrm{p}_{0_{\mathrm{s}^{\prime}} \mathrm{s}}^{\mathrm{m}}+\mathrm{n}_{0_{\mathrm{s}^{\prime}} \mathrm{s}}^{\mathrm{f}} \mathrm{p}_{0_{\mathrm{s}^{\prime}}}^{\mathrm{f}}\right) \mathrm{R}^{\mathrm{s}-\mathrm{t},}
\end{aligned}
$$

where $\mathrm{n}_{0_{\mathrm{S}} \mathrm{S}}^{\mathrm{x}}$ is the generational account of the generation of sex $\mathrm{x}$ aged 0 in year $\mathrm{s}$, and $\mathrm{p}_{0_{\mathrm{S}} \mathrm{s}}^{\mathrm{x}}$ is the population of such individuals in year $\mathrm{S}$. To normalize the generational accounts of each future generation to that of the males of that generation, let $\phi^{\mathrm{m}}$ be 1 , so that $\phi^{\mathrm{f}}=\mathrm{n}_{0_{\mathrm{S}} \mathrm{s}}^{\mathrm{f}} /$ $\mathrm{n}_{0_{\mathrm{S}^{\prime}}, \mathrm{s}}^{\mathrm{m}} \mathrm{s}=\mathrm{t}+1, \ldots \infty$, is the ratio of the generational account of future females born in year $s$ to that of future males born in year s. Further, let the generational accounts of future males grow generation by generation at rate $g$, so that $\mathrm{n}_{0_{\mathrm{s}+1}, \mathrm{~s}+1}^{\mathrm{m}} / \mathrm{n}_{0_{\mathrm{s}}, \mathrm{s}}^{\mathrm{m}}=(1+\mathrm{g}), \mathrm{s}=\mathrm{t}, \ldots \infty$. Dividing and multiplying the right side of equation (A7) by $\mathrm{n}_{0_{\mathrm{t}+1}}^{\mathrm{m}} \mathrm{t}+1$ and manipulating the expression within parentheses yields

$$
\begin{aligned}
& n_{0_{t+1}}^{m} t+1=P V G_{t}-N W G_{t}-P V L_{t} / \\
& \sum_{s=t+1}^{\infty}\left(p_{0_{s^{\prime}} s}^{m}+\phi p_{0_{s^{\prime}} s}^{f}\right) R^{s-t}(1+g)^{s-(t+1)} .
\end{aligned}
$$

The term on the left side of equation (A8) is the generational account as of year $t+1$ for males born in that year, and $\mathrm{n}_{0_{t+1}}^{\mathrm{f}} \mathrm{t+1}=$ $\phi^{\mathrm{f}} \mathrm{n}_{\mathrm{O}_{\mathrm{t}+1}, \mathrm{t}+1}^{\mathrm{m}}$ is the generational account for females born in that year. ${ }^{33}$ Because at any time $t$, both newborns and future generations have their entire lives ahead of them, it is legitimate to compare the generational accounts of the generation born in year $t$ to that of the generation born in year $t+1$. Note, again, that the latter represents an equal (growth-adjusted) distribution among future generations of the aggregate residual burden, $\mathrm{PVF}_{\mathrm{t}}$. The difference

32 Many yearly government purchases, such as for defense and general administration, cannot be assigned to specific age groups and are prorated to all individuals alive in that year. Note that generational accounting uses estimates of government purchases by age only to mechanically extend the projections of those purchases. Ordinarily, it does not try to assign the benefits of purchases by age and sex.

33 Note that the summation in the denominator goes to infinity, while our population projections extend only through 2200 . The calculations assume that beyond that year, the size and the age composition of the population remain fixed at their 2200 levels. 
between the measures for current newborns and future generations computed as a percentage,

$$
P=\left(\frac{n_{0_{t+1}}^{m} t+1}{n_{0_{t}, t}^{m}(1+g)}\right) \times 100,
$$

provides a gauge of the degree of "imbalance" implied by the assumed fiscal policy.

An alternative measure of the fiscal burden on a generation is the lifetime net tax rate that it faces under the assumed policy. This rate is computed as the ratio of the generational account at birth to the present value at birth of per capita labor income over the generation's entire life. Thus, we can express the lifetime net tax rate, $\tau$, as

$$
\tau_{\mathrm{j}_{\mathrm{t}^{\prime}} \mathrm{x}-\mathrm{j}_{\mathrm{t}}}^{\mathrm{x}}=\frac{\mathrm{n}_{\mathrm{j}_{\mathrm{t}}, \mathrm{t}-\mathrm{j}_{\mathrm{t}}}^{\mathrm{x}}}{\sum_{\mathrm{s}=\mathrm{t}-\mathrm{j}_{\mathrm{t}}} \lambda_{\mathrm{j}_{\mathrm{t}}, \mathrm{s}}^{\mathrm{x}} \mathrm{R}^{\mathrm{s}-(\mathrm{t}-\mathrm{jt})}},
$$

where $\tau_{\mathrm{j}^{\prime}}^{\mathrm{x}} \mathrm{t}-\mathrm{j}_{\mathrm{t}}$ is the lifetime net tax rate of the generation of sex $x$ aged $j$ in year $t$, and $\lambda_{j_{t}}^{\mathrm{x}}$, is this generation's per capita labor eamings in year s. ${ }^{34}$ Note that net taxes are summed over the entire life of the generation, and the present values for both the numerator and the denominator are computed as of the generation's year of birth, $t-\mathrm{j}_{\mathrm{t}}$. The lifetime net tax rate represents the fraction of the present value at birth of lifetime labor eamings that will be paid to the government. Hence, in computing lifetime net tax rates for living generations, it is necessary to include past as well as prospective net taxes in the numerator, and past as well as prospective labor earnings in the denominator.

34 Ideally, the method would use lifetime total income, including income from labor and capital and (private) net transfers from other generations. To the extent that capital income represents the normal return on saving, the present value of this income equals the amount of that saving. If this were the only source of income other than labor, the present value at birth of a generation's total income would equal that of its labor income. However, if a generation receives higher-than-normal returns on saving (including capital gains) and/or private net transfers from other generations, this result will not be true. The difference due to these items is typically less than 10 percent, but unlikely to be as large as 20 percent. Because of a lack of reliable data on these income sources, generational accounting ignores private intergenerational transfers and extranormal returns in computing lifetime net tax rates.

\section{References}

Altonji, J., F. Hayashi, and L.J. Kotlikoff. "Is the Extended Family Altruistically Linked? Direct Tests Using Micro Data," American Economic Review, vol. 82, no. 5 (December 1992), pp. 1177-98.

$$
\text { , and _._._._. . Parental }
$$

Altruism and Inter Vivos Transfers: Theory and Evidence," Journal of Political Economy, vol. 105, no. 6 (December 1997), pp. 1121-66.

\section{Auerbach, A.J., J. Gokhale, and L.J. Kotli-} koff. "Generational Accounts: A Meaningful Alternative to Deficit Accounting," in D. Bradford, ed., Tax Policy and the Economy, vol. 5. Cambridge, Mass.: MT Press and the National Bureau of Economic Research, 1991, pp. 55-110.

Accounting: A Meaningful Way to Evaluate Fiscal Policy," Journal of Economic Perspectives, vol. 8, no. 1 (Winter 1994), pp. 73-94.

Generational Balance in U.S. Fiscal Policy: What Will It Take?' Federal Reserve Bank of Cleveland, Economic Review, vol. 31, no. 1 (Quarter 1 1995), pp. 2-12.

Congressional Budget Office. Who Pays and When: An Assessment of Generational Accounting, November 1995.

. Long-term Budgetary Pressures and Policy Options, March 1997a.

. An Economic Model for Long-run Budget Simulations, July 1997b.

. The Economic and Budget Outlook: An Update. Washington, D.C.: U.S. Government Printing Office, September 1997c.

Eisner, R. "The Grandkids Can Relax," The Wall Street Journal, November 9, 1994.

Gokhale, J.J. "Demographic Change, Generational Accounts, and National Saving in the United States," in A. Mason and G. Tapinos, eds., Sharing the Wealth: Demographic Transfers and Economic Transfers between Generations. International Union for the Scientific Study of Population, 1998 (forthcoming). 
Haveman, R. "Should Generational Accounts Replace Public Budgets and Deficits?' Journal of Economic Perspectives, vol. 8, no. 1 (Winter 1994), pp. 95-111.

Health Care Financing Administration. Annual Report of the Board of Trustees of the Federal Hospital Insurance Trust Fund, 1997.

Kotlikoff, L.J. Generational Accounting: Knowing Who Pays, and When, for What We Spend. New York: The Free Press, 1992.

Social Security Administration. Annual Report of the Board of Trustees of the Federal Old-Age and Survivors Insurance and Disability Insurance Trust Funds, 1997.

U.S. Department of Education. Digest of Education Statistics, 1995. Office of Educational Research and Improvement, National Center for Education Statistics, Washington, D.C.: U.S. Government Printing Office, 1997. 


\section{Does Intervention Explain the Forward Discount Puzzle?}

by William P. Osterberg

\begin{abstract}
William P. Osterberg is an economist at the Federal Reserve Bank of Cleveland. He thanks Joseph Haubrich, Owen Humpage, Peter Rupert, and James Thomson for helpful comments and suggestions, and Jennifer DeRudder for research assistance.
\end{abstract}

\section{Introduction}

Although neither the Federal Reserve System nor the U.S. Treasury has intervened in foreign exchange markets since August 1995, the policy has not been officially abdicated by the United States, Germany, or Japan. ${ }^{1}$ Several Southeast Asian central banks have conducted interventions recently in an attempt to maintain exchange-rate pegs and counter the volatility associated with capital flows. This implies a belief that intervention can alter either the level or the volatility of exchange rates. ${ }^{2}$

A large body of research, however, questions intervention's usefulness, generally finding that the policy has consequences that seem to vary with the period being studied, effects that are inconsistent with the theoretical mechanisms through which intervention might operate, and ultimately, little impact. Such findings must be evaluated in light of the general failure of economic theories of exchange-rate movements when it comes to explaining actual rates. Unfortunately, most central banks provide little day-to-day information about intervention actions, making it difficult to test hypotheses about intervention's effectiveness. This lack of data supports speculation that intervention might explain some of the anomalies in international finance.

Recent research has provided insight into one such anomaly-the forward discount puzzle. This refers to the finding that the currencies of countries with high interest rates appreciate in value, instead of declining, as uncovered interest parity (UIP) might imply. The relevance of the relationship between interest-rate differentials and movements in currency values is obvious from even a casual perusal of the financial press' analyses of currency market developments. These stories usually explain currency appreciations in terms of unexpected economic strength, which would imply higher short-term interest rates. One might be tempted to conclude that the financial press accepts the

1 By law, the Treasury could intervene alone. Typically, however, the Treasury and the Federal Reserve act together and with equal authority. All official exchange-market transactions are conducted by the Federal Reserve Bank of New York, which maintains one account for the Treasury and one for the Federal Reserve (see Humpage [1994] for further discussion).

2 It is not clear at this time whether the 1997 intervention operations conducted by Southeast Asian central banks were sterilized so as to have no direct impact on monetary aggregates. Unsterilized intervention is not distinct from monetary policy. 
anomaly as fact. ${ }^{3}$ The forward discount puzzle can also be described as the finding that the forward rate on foreign exchange predicts the wrong direction of movement for the spot exchange rate. The myriad studies that have focused on this puzzle have been dominated by issues of statistical inference, although a few papers have demonstrated a role for exchangerate policies.

In this article, I utilize official data on U.S. and German central bank interventions to examine the connection between these actions and the forward discount puzzle for the German mark/U.S. dollar (DM/\$) and Japanese yen/U.S. dollar (Yen/\$) exchange rates from 1985 to 1991 . This work is motivated partly by the findings of Flood and Rose (1996; henceforth FR) that countries with higher interest rates are more likely to have their currencies appreciate (the forward discount puzzle) if their exchange rate is floating rather than fixed.

Another motivation comes from evidence, presented in Baillie and Osterberg (1997), that is consistent with intervention affecting a risk premium in the forward market. Because interventions are often motivated by a desire to influence the level (or volatility) of the exchange rate, by some measures they could be related to the distinction between fixed and floating exchange-rate regimes. ${ }^{4}$ I thus estimate regressions of exchange-rate changes on interest-rate differentials for the full sample period and for subperiods when intervention was relatively heavy or when policymakers expressed willingness to intervene. At least for the $\mathrm{DM} / \mathrm{\$}$, the forward discount puzzle is stronger during the interventionist subperiods. This appears to strengthen FR's finding that policy is an important determinant of exchange rates' response to interest-rate differentials.

This article is organized as follows: Section I reviews the relevant portion of the literature analyzing the impact of central bank intervention. Section II summarizes recent studies of the forward discount puzzle, including some papers that suggest a role for intervention. Section III discusses the data and the simple analytical framework used here to discover if intervention might explain a portion of the puzzle. Section IV presents the results, and section V states the conclusions.

\section{Evidence on the Impact of Central Bank Intervention}

Thorough summaries of evidence on the impact of central bank intervention are provided by Edison (1993) and Almekinders (1995). Typically, U.S. intervention operations are sterilized by an offsetting transaction with govemment securities that leaves the monetary aggregates unaffected. Because nonsterilized intervention can be considered a form of monetary policy, most research has focused on sterilized intervention, which is usually thought to operate either through a portfolio balance channel or by giving the marketplace signals of future government policies. In the former case, the magnitude of an intervention's impact is predicted to depend on the size of the intervention relative to the portfolios of investors choosing between government debt denominated in different currencies. ${ }^{5}$ Given the immensity of currency holdings, it is perhaps not surprising that researchers have usually found no significant portfolio balance effect. The signaling channel would be operative if the intervening authorities had information not already available to the market. Such information might take the form of economic data, which, if public, would suggest a higher market value for the currency. The information could also take the form of policy intentions to boost the value of the currency.

Generally, evidence regarding the portfolio balance channel has been negative. Although some impact is found, the coefficients' signs are often inconsistent with the theory, one implication of which is that purchases of domestic currency - and the offsetting sales of domestic government securities- could induce investors to hold relatively more domestic securities only if the domestic currency increased in value. However, the empirical performance of models of the risk premium in foreign exchange rates has generally been unsatisfactory.

3 On the other hand, as can be inferred from equation (1), UIP directly implies that interest differentials correspond only to expected exchange-rate movements, not to actual movements. Thus, an apparently anomalous increase in the currency value might itself be associated with an expected depreciation that is greater than before.

4 However, it is unclear what measure of intervention is relevant in this context. Obvious candidates include the frequency of intervention and its magnitude.

5 The portfolio balance theory rests on two key assumptions: first, that investors view bonds of different currency denominations as imperfect substitutes, and second, that Ricardian equivalence does not hold. 
Research on the signaling channel has had little more success in explaining the comovements of intervention, monetary aggregates, interest rates, and exchange rates. This likewise might not seem surprising, considering the failure of monetary models of exchange-rate determination. After all, if monetary policy has little predictive power for exchange rates, why should we expect intervention's impact on exchange rates to be consistent with the future monetary decisions that intervention implies? The signaling mechanism does not make sense unless the impact of intervention on exchange rates (for example, U.S. authorities buying German marks with U.S. dollars, thus increasing $\mathrm{DM} /$ ) is generally consistent with subsequent monetary policy (such as decreased U.S. interest rates). Klein and Rosengren (1991) find no predictable relationship between intervention and monetary policy, and Kaminsky and Lewis (1996) report that intervention's impact on exchange rates is sometimes inconsistent with the monetary policy it appears to signal. ${ }^{6}$

\section{Recent Research on the Forward Discount Puzzle}

The forward discount puzzle can be understood by considering two separate relations. Equation (1) states UIP that equates the expected gross return at time t from investing one U.S. dollar for a period of length $k$ at rate $r_{t, k}$ with the expected gross return from converting the dollar to a foreign currency (at rate $s_{\mathrm{t}}$, which denotes foreign currency units per dollar), investing the proceeds at the foreign rate $\mathrm{r}_{\mathrm{t}, \mathrm{k}} *$, and converting back to U.S. dollars at the future exchange rate $s_{t+k} \cdot{ }^{7}$

$$
\mathrm{E}_{\mathrm{t}}\left(1+\mathrm{r}_{\mathrm{t}, \mathrm{k}}\right)=\mathrm{E}_{\mathrm{t}}\left[\mathrm{s}_{\mathrm{t}}\left(1+\mathrm{r}_{\mathrm{t}, \mathrm{k}}{ }^{*}\right) / \mathrm{s}_{\mathrm{t}+\mathrm{k}}\right] .
$$

In this equation, only the future exchange rate is unknown, and $\mathrm{E}_{\mathrm{t}}$ refers to the expectation based on knowledge available at time $t$.

A second relation defines the risk premium as the difference between the expected future spot exchange rate and the current forward rate that would settle on the same date as the future spot rate. Thus, the difference between the actual future spot rate and the forward rate equals the risk premium plus an error term equaling the difference between the actual and expected future spot rates $\left(\mathrm{u}_{\mathrm{t}, \mathrm{k}}\right)$ :

$$
\mathrm{s}_{\mathrm{t}, \mathrm{k}}-\mathrm{f}_{\mathrm{t}, \mathrm{k}}=\rho_{\mathrm{t}, \mathrm{k}}+\mathrm{u}_{\mathrm{t}, \mathrm{k}}
$$

In (2), s and $f$ refer to the logarithms of the spot and forward rates.

Equation (1) is often rewritten as

$$
s_{t+k}-s_{t}=r_{t, k} *-r_{t, k}+v_{t, k},
$$

where $\mathrm{s}$ and $\mathrm{r}$ are in logarithms, and $\mathrm{v}$ reflects the difference between the actual and expected future spot rate. UIP is usually tested by estimating (4):

$$
\mathrm{s}_{\mathrm{t}+\mathrm{k}}-\mathrm{s}_{\mathrm{t}}=\alpha+\beta_{\mathrm{r}}\left(\mathrm{r}_{\mathrm{t}, \mathrm{k}} *-\mathrm{r}_{\mathrm{t}, \mathrm{k}}\right)+\mathrm{v}_{\mathrm{t}, \mathrm{k}} .
$$

The forward discount puzzle is that $\beta_{\mathrm{r}}$, estimated from (4), is usually negative instead of being equal to +1 , as implied by (3). The findings regarding (4) are closely related to the findings when the following version of equation (2) is estimated: ${ }^{8}$

$$
\mathrm{s}_{\mathrm{t}+\mathrm{k}}-\mathrm{s}_{\mathrm{t}}=\alpha+\beta_{\mathrm{f}}\left(\mathrm{f}_{\mathrm{t}, \mathrm{k}}-\mathrm{s}_{\mathrm{t}}\right)+\mathrm{u}_{\mathrm{t}, \mathrm{k}} .
$$

As Engel (1996) carefully documents, econometric estimates of $\beta_{\mathrm{f}}$ are often negative and almost always significantly different from +1 . Recent research, however, has advanced intriguing possibilities for explaining the puzzle. ${ }^{9}$ For example, Baillie and Bollersev (1997) demonstrate that the apparently anomalous estimates of $\beta_{\mathrm{f}}$ might result from a combination of persistent autocorrelation in the forward premium and the small size of the samples typically studied. FR also provide evidence on the importance of the sample when they estimate (4) with pooled data for exchange rates within the exchange-rate mechanism (ERM) of the European Monetary System. The estimate of $\beta_{\mathrm{r}}$ declines when periods of realignment are excluded. This implies that the forward discount puzzle might be explained partly by using samples in which realignments are anticipated more

6 A recent analysis of U.S. intervention in the 1990s (Humpage [1997]) concludes that the authorities apparently had no information supe rior to that of the market. Such a finding is generally inconsistent with the view that intervention signals new information about future monetary policy.

7 Here, "uncovered" refers to the fact that the risk posed by uncertainty about the future exchange rate has not been eliminated (covered) through use of a forward contract or other instrument. In covered interest parity (CIP), the expected future exchange rate in (1) is replaced by the forward rate.

8 Adding $f_{t, k}-s_{t}$ to both sides of (2) yields (5) if the risk premium equals $0, \alpha=0$, and $\beta=1$. Hence, rejecting $\alpha=0$ and $\beta=1$ is often seen as indicating the existence of a risk premium in the forward market. 


\section{F I G U R E 1}

Exchange-Rate Changes and
Interest-Rate Differentials: DM/\$

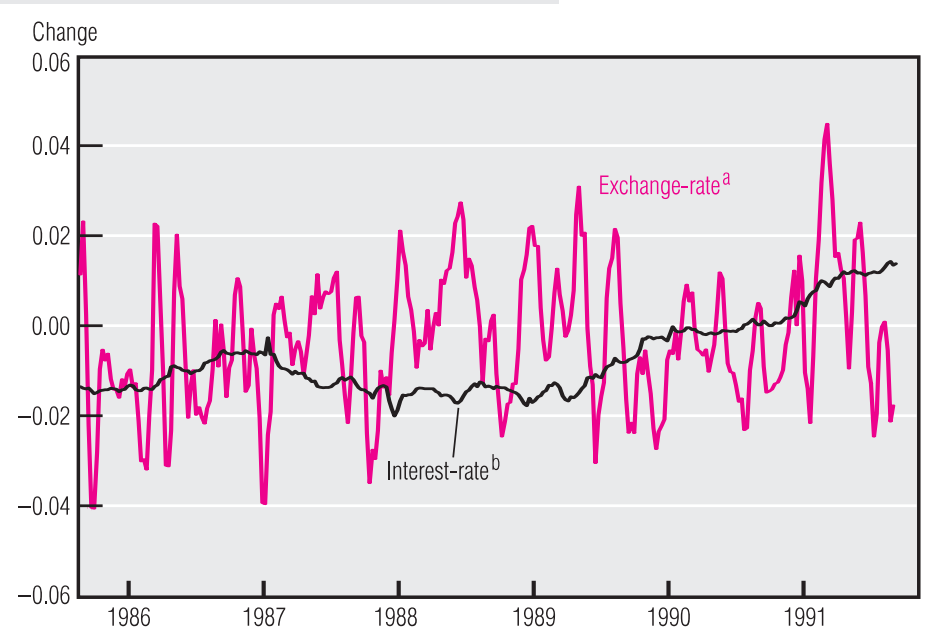

F I G U R E 2

Exchange-Rate Changes and

Interest-Rate Differentials: Yen/\$

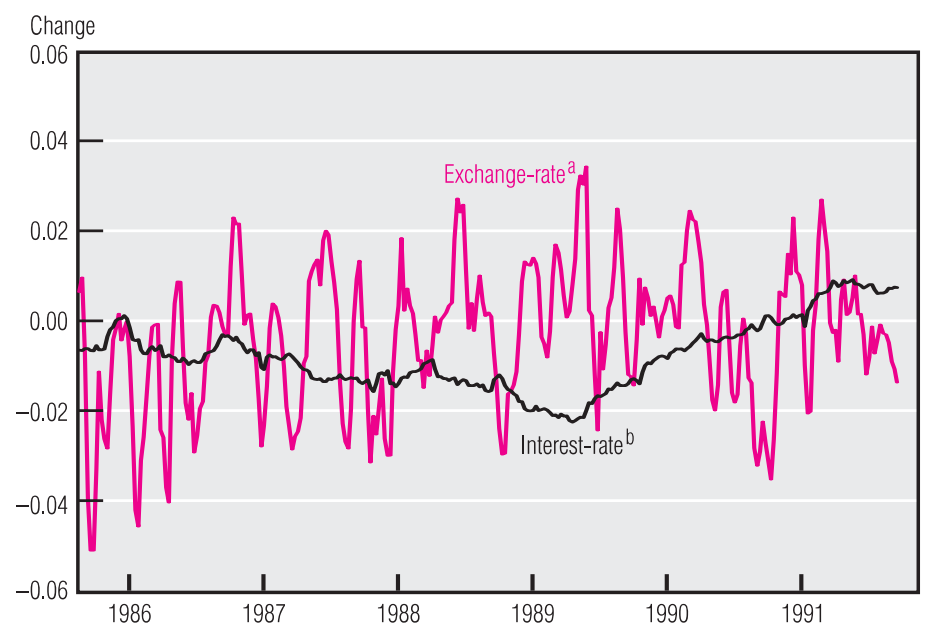

a. Calculated as $\log [\mathrm{s}(\mathrm{t}+\mathrm{k})]-\log [\mathrm{s}(\mathrm{t})]$.

b. Calculated as $\log [1+i *(t)]-\log [1+i *(t)]$.

SOURCE: Author's calculations.

frequently than they occur. This phenomenon is often referred to as the "peso problem."

That monetary policy - or exchange-rate policy - could help explain the anomaly is suggested by the financial press' interpretations of short-term movements in exchange rates. News of unanticipated economic strength is said to bolster a currency's value because interest rates are expected to increase, implying the relevance of expected monetary policy. Obviously, any correlation between interest-rate and exchangerate movements would also be affected by interventions that successfully prevent currency appreciation.

At least three studies suggest that exchangerate policy might provide a partial explanation of the anomaly. FR estimate (4) using floatingrate data for several currencies' quotes against the dollar, and also using fixed-rate data for currencies within the ERM, quoted against the German mark. Their finding that estimates of $\beta_{\mathrm{r}}$ became more positive for the fixed-rate data suggests the importance of exchangerate regimes.

The analysis of (2) in Baillie and Osterberg (1997) shows that central bank intervention influenced risk in the forward market. This points to the existence of a risk premium that can be explained partly by central bank operations. Loopesko (1984) finds that central bank intervention sometimes has explanatory power for deviations from the UIP condition in equation (1). ${ }^{10}$ Taken together, these findings suggest that intervention might be related to the forward discount anomaly. For example, if intervention is interpreted as an attempt to "fix" or control exchange rates, then periods of heavy intervention might be associated with more positive estimates of $\beta_{\mathrm{r}}$.

\section{The Data and the Analytical Framework}

To see if the sign of the estimate of $\beta_{\mathrm{r}}$ varies among periods of light versus heavy intervention, I use the official daily intervention data supplied by the Board of Governors of the Federal Reserve System and the Deutsche Bundesbank, in combination with 9:00 a.m. New York quotes on DM/ \$ and Yen/\$, as well as 3:00 p.m. London 30-day Euromarket interest rates. Figures 1 and 2 depict movements in the logarithm of exchange rates and in the difference in the logarithms of interest rates. The intervention series equal the net sales or purchases of U.S. dollars vis-à-vis the foreign currency over the 24-hour period between consecutive business day closings.

10 Other analyses of the impact of central bank intervention on UIP are summarized by Edison (1993). 


\section{T A B L E 1}

Intervention and Uncovered

Interest Parity: DM/\$

\section{Generalized-Method-of-Moments \\ Estimates of Equation (4)}

$\alpha$ (t-statistic) $\beta$ (t: $\beta=0$

Sample criterion:

By intervention

$\begin{array}{ccc}\text { 9/23/85- } & -0.13 & -3.4 \\ 11 / 12 / 85 & (-3.6) & (-3.1) \\ 3 / 23 / 87- & -0.18 & -6.7 \\ 5 / 4 / 87 & (-6.9) & (-7.0) \\ 8 / 4 / 87- & -0.27 & -9.2 \\ 9 / 9 / 87 & (-8.8) & (-9.5) \\ 10 / 20 / 87- & -0.13 & -3.2 \\ 1 / 11 / 88 & (-4.3) & (-4.3) \\ 6 / 9 / 88- & -0.32 & -10.0 \\ 9 / 27 / 88 & (-5.5) & (-6.1) \\ 12 / 20 / 88- & -0.25 & -7.5 \\ 2 / 7 / 89 & (-10.2) & (-10.4) \\ 4 / 25 / 89- & -0.41 & -14.3 \\ 6 / 30 / 89 & (-10.2) & (-13.7) \\ 8 / 11 / 89- & -0.02 & 0.6 \\ 10 / 11 / 89 & (-1.5) & (0.6) \\ 8 / 6 / 85-\text { end } & -0.01 & 0.06 \\ & (-1.5) & (0.3)\end{array}$

Sample criterion:

EMS realignments ${ }^{\mathrm{a}}$

$\begin{array}{ccc}\text { 8/6/85- } & 0.08 & 3.25 \\ 3 / 27 / 86 & (0.85) & (1.1) \\ 4 / 21 / 86- & -0.03 & -0.22 \\ 7 / 25 / 86 & (-0.3) & (-0.1) \\ 8 / 18 / 86- & 0.03 & 3.95 \\ 12 / 31 / 87 & (0.5) & (0.8) \\ 1 / 26 / 87- & -0.04 & -1.46 \\ 12 / 29 / 89 & (-4.0) & (-3.6) \\ 1 / 22 / 90- & 0.02 & 7.7 \\ 5 / 16 / 90 & (5.8) & (5.2) \\ 8 / 6 / 85- & -0.02 & -0.6 \\ 5 / 15 / 90 & (-3.0) & (-1.8) \\ & & \end{array}$

Description

Plaza Accord

Louvre Accord

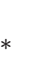

After 10/87 crash

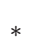

$*$

*

$*$

*

$*$

Full sample

\section{Intervention Data (Number of observations)}

Total Unilateral Coordinated Buy/Sell

Sample criterion:

By intervention

9/23/85-

$\begin{array}{lllll}11 / 12 / 85 & 35 & 19 & 8 & 0 / 27\end{array}$

$3 / 23 / 87$

$5 / 4 / 87$

$8 / 4 / 87$

$9 / 9 / 87$

$10 / 20 / 87-$

$1 / 11 / 88$

$6 / 9 / 88-$

$9 / 27 / 88$

$12 / 20 / 88-$

$2 / 7 / 89$

$4 / 25 / 89$

$6 / 30 / 89$

$8 / 11 / 89-$

$10 / 11 / 89$

8/6/85- end $\quad 1,485$

28

3

1

$4 / 0$

6

$4 \quad 5 / 5$

26

55

10

$17 \quad 30 / 0$

76

28

$29 \quad 0 / 57$

33

15

$12 \quad 0 / 27$

10

$16 \quad 0 / 25$

11

$14 \quad 0 / 25$

$30 \quad 107 / 206$

Sample criterion:

EMS realignments ${ }^{\mathrm{a}}$

$8 / 6 / 85$

$\begin{array}{lrrrr}\begin{array}{c}3 / 27 / 86 \\ 4 / 21 / 86-\end{array} & 157 & 26 & 8 & 6 / 28 \\ 7 / 25 / 86 & 64 & 10 & 0 & 10 / 0 \\ \begin{array}{c}8 / 18 / 86- \\ 12 / 31 / 87\end{array} & 90 & 8 & 0 & 7 / 1 \\ \begin{array}{c}1 / 26 / 87- \\ 12 / 29 / 89\end{array} & 720 & 113 & 105 & 56 / 162 \\ \begin{array}{c}1 / 22 / 90- \\ 5 / 16 / 90\end{array} & 79 & 2 & 2 & 0 / 2 \\ \begin{array}{c}8 / 6 / 85- \\ 5 / 15 / 90\end{array} & 1,167 & 253 & 26 & 83 / 196\end{array}$

a. See Flood, Rose, and Mathieson (1991).

NOTE: Asterisks indicate periods of relatively heavy intervention. Numbers in parentheses are t-statistics.

SOURCE: Author's calculations.

The sample period extends from August 6, 1985 through September 6, 1991, a period that includes two well-publicized Group of Three (G-3) attempts to influence dollar exchange rates. ${ }^{11}$ The Plaza Accord in September 1985 stipulated that the G-3 countries' central banks would intervene to bring down the level of the dollar, and the Louvre Accord of February 1987 included statements that central banks would strive to reduce fluctuations in the dollar. Other periods of intervention were defined by examining the actual intervention time series.
These periods were characterized by relatively heavy or consistent intervention by one or two of the central banks.

We utilize a generalized-method-of-moments (GMM) technique to account for the fact that the error term appearing on the right side of (3) has a high-order moving average representation because the data are daily observations on a 


\section{T A B L E 2}

Intervention and Uncovered

Interest Parity: Yen/\$

\section{Generalized-Method-of-Moments \\ Estimates of Equation (4)}

\begin{tabular}{|c|c|c|c|}
\hline \multirow[b]{2}{*}{$\begin{array}{l}\text { Sample criterion: } \\
\text { By intervention }\end{array}$} & $\alpha$ (t-statistic) & $\boldsymbol{\beta}(\mathrm{t}: \boldsymbol{\beta}=\mathbf{0})$ & Description \\
\hline & & & \multirow[b]{2}{*}{ Plaza Accord } \\
\hline $\begin{array}{l}9 / 23 / 85- \\
11 / 12 / 85\end{array}$ & $\begin{array}{l}-0.02 \\
(-2.0)\end{array}$ & $\begin{array}{c}3.1 \\
(4.9)\end{array}$ & \\
\hline $\begin{array}{r}4 / 16 / 86- \\
8 / 7 / 86\end{array}$ & $\begin{array}{l}0.09 \\
(2.6)\end{array}$ & $\begin{array}{c}5.8 \\
(2.6)\end{array}$ & * \\
\hline $\begin{array}{c}3 / 24 / 87- \\
4 / 27 / 87\end{array}$ & $\begin{array}{l}-0.3 \\
(-6.3)\end{array}$ & $\begin{array}{l}-11.3 \\
(-6.6)\end{array}$ & Louvre Accord \\
\hline $\begin{array}{c}8 / 13 / 87- \\
9 / 9 / 87\end{array}$ & $\begin{array}{l}0.13 \\
(2.9)\end{array}$ & $\begin{array}{l}3.9 \\
(2.7)\end{array}$ & $*$ \\
\hline $\begin{array}{r}10 / 27 / 87- \\
1 / 21 / 88\end{array}$ & $\begin{array}{c}0.08 \\
(-1.1)\end{array}$ & $\begin{array}{l}-2.3 \\
(-1.1)\end{array}$ & After 10/87 crash \\
\hline $\begin{array}{l}3 / 15 / 88- \\
4 / 20 / 88\end{array}$ & $\begin{array}{l}-0.02 \\
(-2.9)\end{array}$ & $\begin{array}{l}-0.9 \\
(-3.4)\end{array}$ & * \\
\hline $\begin{array}{r}10 / 27 / 88- \\
12 / 8 / 88\end{array}$ & $\begin{array}{l}-0.08 \\
(-1.8)\end{array}$ & $\begin{array}{l}-2.3 \\
(-2.4)\end{array}$ & * \\
\hline $\begin{array}{l}4 / 28 / 89- \\
7 / 21 / 89\end{array}$ & $\begin{array}{l}0.26 \\
(4.1)\end{array}$ & $\begin{array}{c}7.0 \\
(3.9)\end{array}$ & * \\
\hline $\begin{array}{l}8 / 7 / 89- \\
10 / 12 / 89\end{array}$ & $\begin{array}{l}0.08 \\
(4.5)\end{array}$ & $\begin{array}{c}3.2 \\
(4.2)\end{array}$ & * \\
\hline $\begin{array}{l}2 / 23 / 90- \\
4 / 19 / 90\end{array}$ & $\begin{array}{l}0.27 \\
(5.4)\end{array}$ & $\begin{array}{l}28.8 \\
(5.7)\end{array}$ & * \\
\hline $\begin{array}{r}8 / 6 / 85- \\
9 / 6 / 91\end{array}$ & $\begin{array}{l}-0.01 \\
(-2.4)\end{array}$ & $\begin{array}{l}-0.2 \\
(-1.1)\end{array}$ & Full sample \\
\hline \multicolumn{4}{|c|}{ Intervention Data (Number of observations) } \\
\hline & Total & U.S. Buy & U.S. Sell \\
\hline
\end{tabular}

Sample criterion:

By intervention

9/23/85-

$11 / 12 / 85$

$4 / 16 / 86-$

$8 / 7 / 86$

$3 / 24 / 87-$

$4 / 27 / 87$

$8 / 13 / 87$

$9 / 9 / 87$

$10 / 27 / 87-$

$1 / 21 / 88$

$3 / 15 / 88-$

$4 / 20 / 88$

$10 / 27 / 88-$

$12 / 8 / 88$

$4 / 28 / 89$

$7 / 21 / 89$

$8 / 7 / 89$

$10 / 12 / 89$

$2 / 23 / 90$

$4 / 19 / 90$

8/6/85- end

(1018: Astensks indicate peniods

$\begin{array}{rrr}34 & 0 & 20 \\ 76 & 0 & 0 \\ 23 & 16 & 0 \\ 19 & 5 & 4 \\ 57 & 22 & 0 \\ 25 & 5 & 0 \\ 28 & 13 & 0 \\ 56 & 0 & 34 \\ 47 & 0 & 28 \\ 38 & 0 & 13 \\ 1,464 & 66 & 116\end{array}$

parentheses are t-statistics.

SOURCE: Author's calculations. one-month interest-rate contract. I have matched the future spot rate with the one-month Eurocurrency interest rate so that both settle on the same day. As Baillie and Osterberg (1997) point out, this implies an MA(21) representation. The standard emrors used to calculate the t-statistics in the tables are also corrected for heteroscedasticity. The instrumental variables chosen are a constant, the lagged interest-rate differential, and the lagged change in the logarithm of the exchange rate. Hamilton (1994, chapter 10) provides a useful review of the issues involved in GMM estimation.

\section{Results}

Table 1 presents the results of estimating equation (4) for the DM/ \$. For the entire sample period, the estimate of $\beta$ is slightly positive but significantly less than one. The finding that the coefficient is slightly positive is unusual, indicating that the results may be sensitive to the sample. However, for seven of the eight intervention periods, the estimate of $\beta$ is not only significantly different from one but also significantly negative. ${ }^{12}$ For comparison with FR, I estimated equation (3) for the periods between EMS realignments. Unlike FR, I find that the sign of the estimated $\beta$ does not seem to depend on whether these periods are excluded from estimation. However, the realignments and the analysis in FR pertain to exchange rates of the European currencies vis-à-vis the German mark. Apparently, the ERM realignments were not reflected in the DM/ \$ or in the U.S. and German interventions vis-à-vis the $\mathrm{DM} / \$$.

Table 2 presents similar results from estimating equation (4) for the Yen/\$. The full-sampleperiod estimate of $\beta$ is negative and significantly different from one. However, the results for the subperiods provide less encouragement that intervention could somehow explain the forward discount puzzle: In only four of the 10 subperiods were the estimates of $\beta$ significantly negative. It is interesting that, in six of these intervals, the estimate was significantly greater than one. ${ }^{13}$ Overall, for the two currencies, 11 of the 18 subperiods showed estimates of $\beta_{\mathrm{r}}$ that were significantly less than zero.
12 These results appear to be robust to slight variations in the length of the intervention periods.

13 On the other hand, when I estimate the same equation for the full sample period, including intercept and slope dummies equal to one for the intervention periods, both dummies differ significantly from zero. 
The second half of each table provides summary data on U.S. and/or German intervention. In table 2, only official information about U.S. intervention against the yen is available. Baillie and Osterberg (1997) find evidence consistent with the idea that U.S. buying - but not selling - of dollars affects risk in the forward market. Here, I find that in the case of the DM/ \$, $\beta$ is negative whether the intervention activity was buying or selling. In the case of the Yen/\$, on the other hand, buying dollars is associated with a negative estimate of $\beta$, while selling implies a positive estimate.

\section{Conclusion}

My evidence on the importance of intervention for the forward discount puzzle is strongest for the $\mathrm{DM} / \$$. However, whereas FR find that $\beta$ became positive under fixed-rate regimes, I find significantly negative estimates for intervention periods. This suggests at least a need to clarify the correspondence between my choice of intervention periods and shifts between floatingand fixed-rate regimes. However, the results presented here are even more interesting when one notes that estimated $\beta$ was also negative for both exchange rates following the Plaza and Louvre agreements. Prior to each of these periods, public statements indicated the likelihood of coordinated efforts to influence exchange rates. Thus, we would have expected the results in both instances to be similar to FR's findings for fixed-rate regimes.

The results also suggest that it would be valuable to examine more closely the hypothesis that buying currencies and selling them have different impacts. It is certainly possible that market conditions have varied between periods of buying and periods of selling. Noisetrading analyses, such as Hung (1997), discuss the relevance of market thinness and the rules followed by chartists.

Of course, recent research on the importance of sample size places rather stringent qualifications on any conclusions I might draw. Unfortunately, few central banks release highfrequency data on intervention, although the recent collapse of fixed-rate regimes and increasing pressure for transparency on the part of central banks might improve opportunities to study the connection between exchange-rate regimes, interest rates, and intervention.

\section{References}

Almekinders, G. J. Foreign Exchange Intervention: Theory and Evidence. Brookfield, Vt.: Elgar, 1995.

Baillie, R. T., and T. Bollersev. "The Forward Premium Anomaly Is Not as Bad as You Think," Michigan State University, unpublished manuscript, May 1997.

Baillie, R. T., and W. P. Osterberg. "Central Bank Intervention and Risk in the Forward Market," Journal of International Economics, vol. 43, nos. 3/4 (November 1997), pp. 483- 97.

Bansal, R. "An Exploration of the Forward Premium Puzzle in Currency Markets," Review of Financial Studies, vol. 10, no. 2 (Summer 1997), pp. 369- 403.

Edison, H. J. "The Effectiveness of CentralBank Intervention: A Survey of the Literature after 1982," Princeton University, Special Papers in International Economics, No. 18, July 1993.

Engel, C. "The Forward Discount Anomaly and the Risk Premium: A Survey of Recent Evidence," Journal of Empirical Finance, vol. 3, no. 2 ( June 1996), pp. 123-92.

Flood, R. P., and A. K. Rose. "Fixes: Of the Forward Discount Puzzle," Review of Economics and Statistics, vol. 78, no. 4 (November 1996), pp. 748-52.

\section{and D. J. Mathieson.}

"An Empirical Exploration of Exchange-Rate Target Zones," Carnegie-Rochester Conference Series on Public Policy, vol. 35 (Autumn 1991), pp. 7-66.

Hamilton, J. D. Time Series Analysis. Princeton, N.J.: Princeton University Press, 1994.

Humpage, O. F. "Institutional Aspects of U.S. Intervention," Federal Reserve Bank of Cleveland, Economic Review, vol. 30, no. 1 (Quarter 1 1994), pp. 2- 19.

. "Recent U.S. Intervention: Is Less More?' Federal Reserve Bank of Cleveland, Economic Review, vol. 33, no. 3 (Quarter 3 1997), pp. 2- 10. 
Hung, J. H. "Intervention Strategies and

Exchange Rate Volatility: A Noise Trading

Perspective," Journal of International Money and Finance, vol. 16, no. 5 (October 1997), pp. 779-93.

Kaminsky, G. L., and K. K. Lewis. "Does Foreign Exchange Intervention Signal Future Monetary Policy?' Journal of Monetary Economics, vol. 37, no. 2 (April 1996), pp. 285-312.

Klein, M. W., and E. S. Rosengren. "Foreign Exchange Intervention as a Signal of Monetary Policy," Federal Reserve Bank of Boston, New England Economic Review, May/June 1991, pp. 39-50.

Loopesko, B. E. "Relationships among Exchange Rates, Intervention, and Interest Rates: An Empirical Investigation," Journal of International Money and Finance, vol. 3, no. 3 (December 1984), pp. 257- 77. 